\title{
LEVEL II SCOUR ANALYSIS FOR BRIDGE 144 (ROCHVT01000144) on STATE ROUTE 100, crossing the WHITE RIVER, ROCHESTER, VERMONT
}

U.S. Geological Survey Open-File Report 97-7

Prepared in cooperation with

VERMONT AGENCY OF TRANSPORTATION and

FEDERAL HIGHWAY ADMINISTRATION 


\section{LEVEL II SCOUR ANALYSIS FOR BRIDGE 144 (ROCHVT01000144) on STATE ROUTE 100, crossing the WHITE RIVER, ROCHESTER, VERMONT \\ By Erick M. Boehmler and Emily C. Wild}

\section{U.S. Geological Survey}

Open-File Report 97-7

Prepared in cooperation with

VERMONT AGENCY OF TRANSPORTATION

and

FEDERAL HIGHWAY ADMINISTRATION 


\title{
U.S. DEPARTMENT OF THE INTERIOR BRUCE BABBITT, Secretary
}

\author{
U.S. GEOLOGICAL SURVEY \\ Gordon P. Eaton, Director
}

For additional information write to:

District Chief

U.S. Geological Survey 361 Commerce Way

Pembroke, NH 03275-3718
Copies of this report may be purchased from:

U.S. Geological Survey

Branch of Information Services

Open-File Reports Unit

Box 25286

Denver, CO 80225-0286 


\section{CONTENTS}

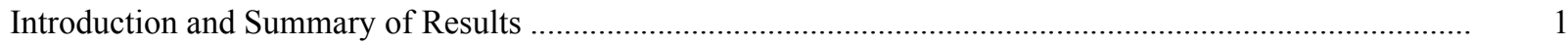

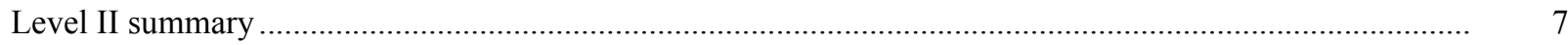

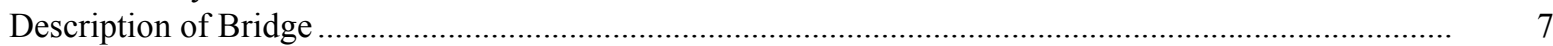

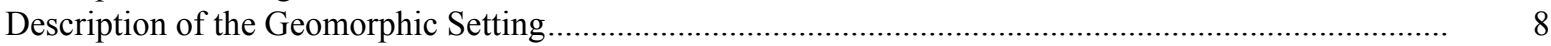

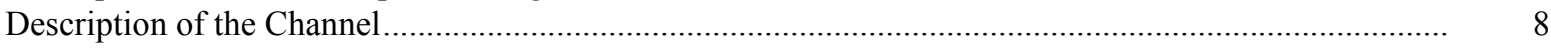

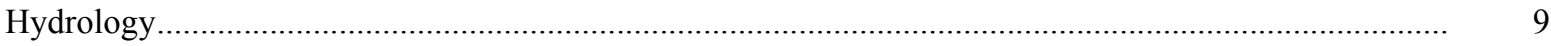

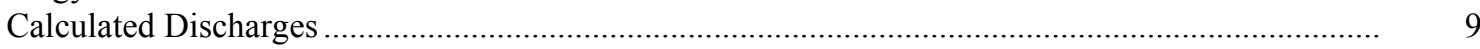

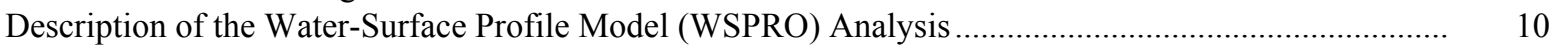

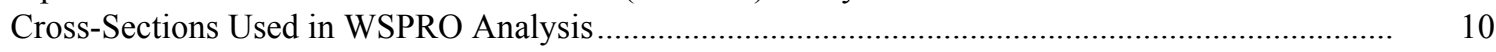

Data and Assumptions Used in WSPRO Model ...................................................................... 11

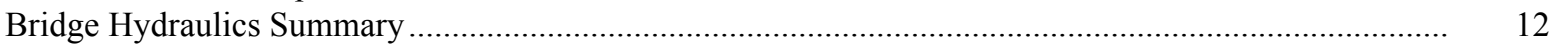

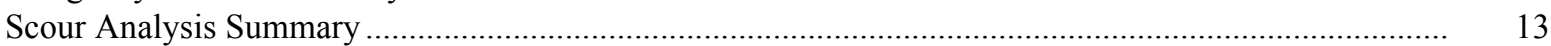

Special Conditions or Assumptions Made in Scour Analysis ...................................................... 13

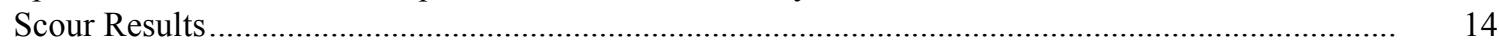

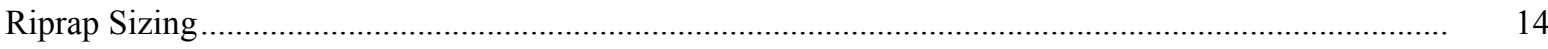

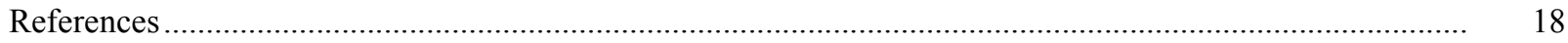

Appendixes:

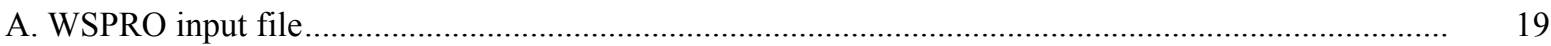

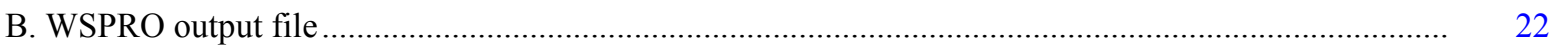

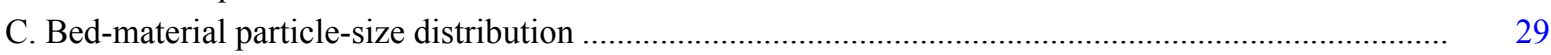

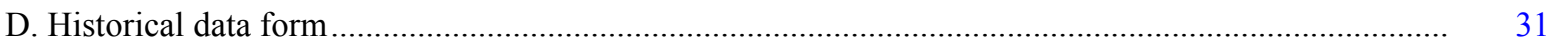

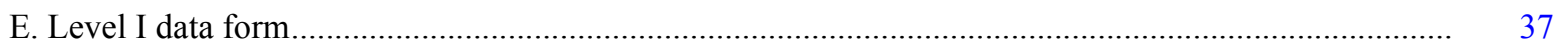

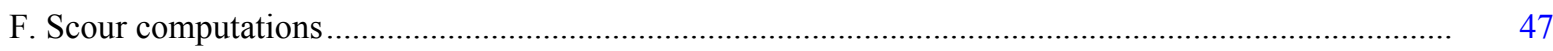

\section{FIGURES}

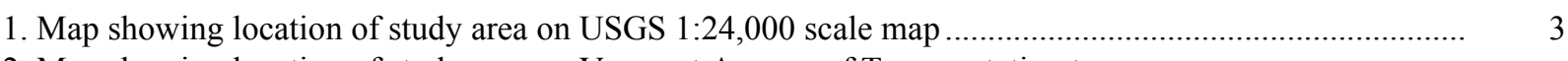

2. Map showing location of study area on Vermont Agency of Transportation town
highway map

3. Structure ROCHVT01000144 viewed from upstream (July 22, 1996) …...............................................

4. Downstream channel viewed from structure ROCHVT01000144 (July 22, 1996).............................. 5

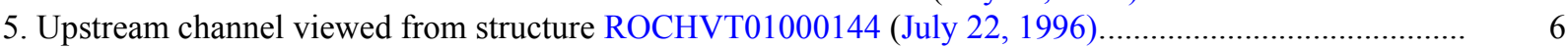

6. Structure ROCHVT01000144 viewed from downstream (July 22, 1996). ......................................... 6

7. Water-surface profiles for the 100- and 500-year discharges at structure ROCHVT01000144 on State Route 100, crossing the White River,

Rochester, Vermont.

8. Scour elevations for the 100- and 500-year discharges at structure

ROCHVT01000144 on State Route 100, crossing the White River,

Rochester, Vermont.

\section{TABLES}

1. Remaining footing/pile depth at abutments for the 100-year discharge at structure

ROCHVT01000144 on State Route 100, crossing the White River,

Rochester, Vermont

2. Remaining footing/pile depth at abutments for the 500-year discharge at structure

ROCHVT01000144 on State Route 100, crossing the White River,

Rochester, Vermont 


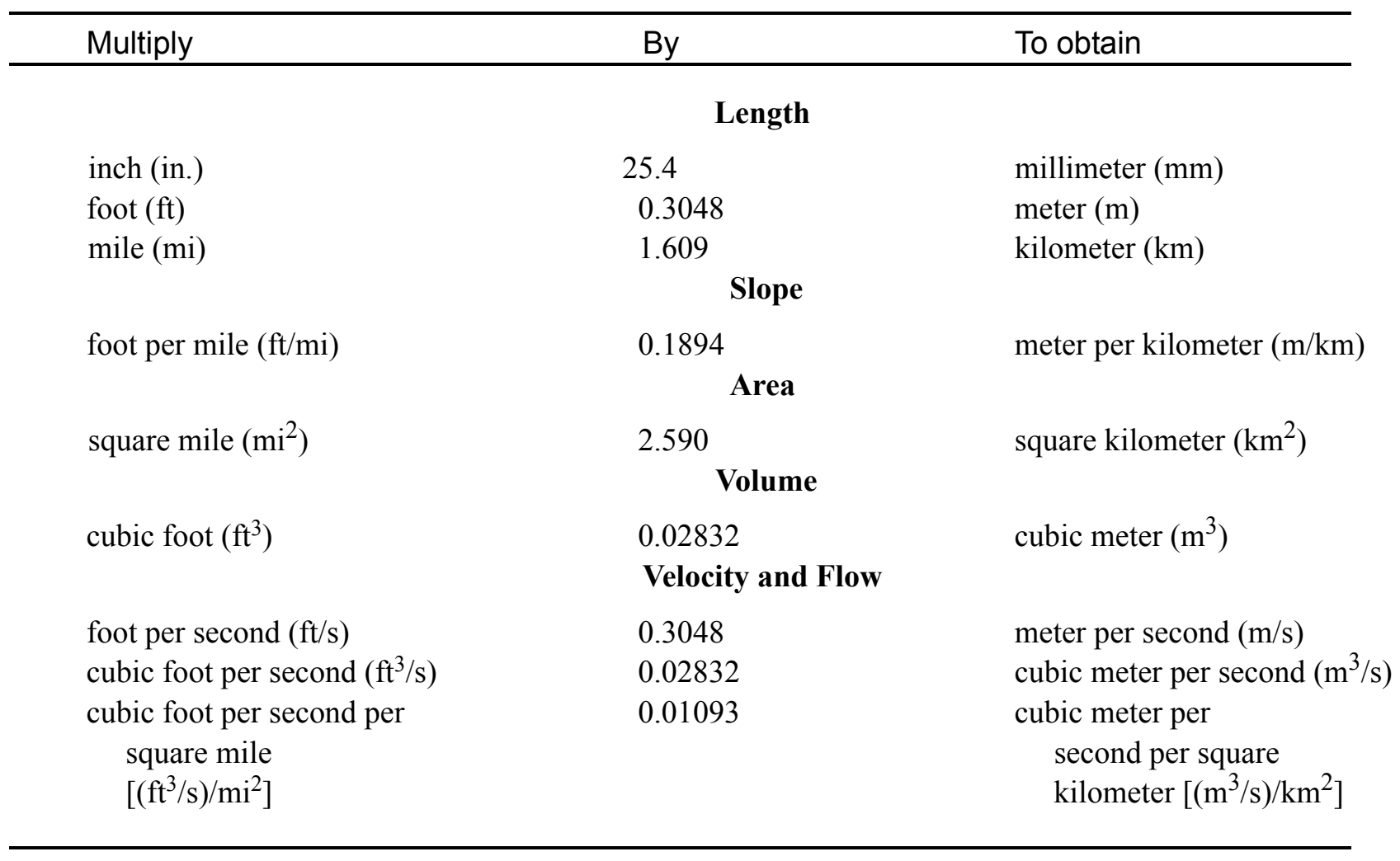

\section{OTHER ABBREVIATIONS}

$\begin{array}{lrlr}\mathrm{BF} & \text { bank full } & \text { LWW } & \text { left wingwall } \\ \mathrm{cfs} & \text { cubic feet per second } & \text { MC } & \text { main channel } \\ \mathrm{D}_{50} & \text { median diameter of bed material } & \text { RAB } & \text { right abutment } \\ \mathrm{DS} & \text { downstream } & \text { RABUT } & \text { face of right abutment } \\ \mathrm{elev} & \text { elevation } & \text { RB } & \text { right bank } \\ \mathrm{f} / \mathrm{p} & \text { flood plain } & \text { ROB } & \text { right overbank } \\ \mathrm{ft}^{2} & \text { square feet } & \text { RWW } & \text { right wingwall } \\ \mathrm{ft} / \mathrm{ft} & \text { feet per foot } & \text { TH } & \text { town highway } \\ \mathrm{JCT} & \text { junction } & \text { UB } & \text { under bridge } \\ \mathrm{LAB} & \text { left abutment } & \text { US } & \text { upstream } \\ \mathrm{LABUT} & \text { face of left abutment } & \text { USGS } & \text { United States Geological Survey } \\ \mathrm{LB} & \text { left bank } & \text { VTAOT Vermont Agency of Transportation } \\ \mathrm{LOB} & \text { left overbank } & \text { WSPRO } & \text { water-surface profile model }\end{array}$

In this report, the words "right" and "left" refer to directions that would be reported by an observer facing downstream. Sea level: In this report, "sea level" refers to the National Geodetic Vertical Datum of 1929-- a geodetic datum derived from a general adjustment of the first-order level nets of the United States and Canada, formerly called Sea Level Datum of 1929.

In the appendices, the above abbreviations may be combined. For example, USLB would represent upstream left bank. 


\title{
LEVEL II SCOUR ANALYSIS FOR BRIDGE 144 (ROCHVT01000144) ON STATE ROUTE 100, CROSSING THE WHITE RIVER, ROCHESTER, VERMONT
}

\author{
By Erick M. Boehmler and Emily C. Wild
}

\section{INTRODUCTION AND SUMMARY OF RESULTS}

This report provides the results of a detailed Level II analysis of scour potential at structure ROCHVT01000144 on State Route 100 crossing the White River, Rochester, Vermont (figures 1-8). A Level II study is a basic engineering analysis of the site, including a quantitative analysis of stream stability and scour (U.S. Department of Transportation, 1993). Results of a Level I scour investigation also are included in Appendix E of this report. A Level I investigation provides a qualitative geomorphic characterization of the study site. Information on the bridge, gleaned from Vermont Agency of Transportation (VTAOT) files, was compiled prior to conducting Level I and Level II analyses and is found in Appendix D.

The site is in the Green Mountain section of the New England physiographic province in central Vermont. The $68.9-\mathrm{mi}^{2}$ drainage area is in a predominantly rural and forested basin. In the vicinity of the study site, the surface cover is pasture with forest on the valley walls.

In the study area, the White River has a meandering channel with a slope of approximately $0.003 \mathrm{ft} / \mathrm{ft}$, an average channel top width of $119 \mathrm{ft}$ and an average channel depth of $4 \mathrm{ft}$. The predominant channel bed material is gravel and cobbles with a median grain size $\left(\mathrm{D}_{50}\right)$ of $72.5 \mathrm{~mm}(0.238 \mathrm{ft})$. The geomorphic assessment at the time of the Level I and Level II site visit on July 22, 1996, indicated that the reach was laterally unstable due to a cut-bank present on the upstream left bank and wide point bars upstream and downstream in the vicinity of this site.

The State Route 100 crossing of the White River is a 103-ft-long, two-lane bridge consisting of one 101-foot steel-beam span (Vermont Agency of Transportation, written communication, March 8, 1995). The bridge is supported by vertical, concrete abutment walls with spill-through embankments in front of each abutment wall and no wingwalls. The channel is skewed approximately 10 degrees to the opening while the opening-skew-toroadway is 5 degrees. 
The scour protection measures at the site are type- 2 stone fill (less than 36 inches diameter) on the upstream left bank, both abutment spill-through embankments, and the downstream banks. There also is type- 1 stone fill (less than 12 inches diameter) on the upstream right bank. The stone fill is continuous on both sides of the river in the vicinity of the bridge. Additional details describing conditions at the site are included in the Level II Summary and Appendices D and E.

Scour depths and rock rip-rap sizes were computed using the general guidelines described in Hydraulic Engineering Circular 18 (Richardson and others, 1995). Total scour at a highway crossing is comprised of three components: 1) long-term streambed degradation; 2) contraction scour (due to accelerated flow caused by a reduction in flow area at a bridge) and; 3) local scour (caused by accelerated flow around piers and abutments). Total scour is the sum of the three components. Equations are available to compute depths for contraction and local scour and a summary of the results of these computations follows.

There was no computed contraction scour for the modelled flows. Abutment scour ranged from 6.9 to $10.9 \mathrm{ft}$. The worst-case abutment scour occurred at the incipient overtopping discharge, which was less than the 100-year discharge. Additional information on scour depths and depths to armoring are included in the section titled "Scour Results". Scouredstreambed elevations, based on the calculated scour depths, are presented in tables 1 and 2. A cross-section of the scour computed at the bridge is presented in figure 8. Scour depths were calculated assuming an infinite depth of erosive material and a homogeneous particlesize distribution.

It is generally accepted that the Froehlich equation (abutment scour) gives "excessively conservative estimates of scour depths" (Richardson and others, 1995, p. 47). Usually, computed scour depths are evaluated in combination with other information including (but not limited to) historical performance during flood events, the geomorphic stability assessment, existing scour protection measures, and the results of the hydraulic analyses. Therefore, scour depths adopted by VTAOT may differ from the computed values documented herein. 


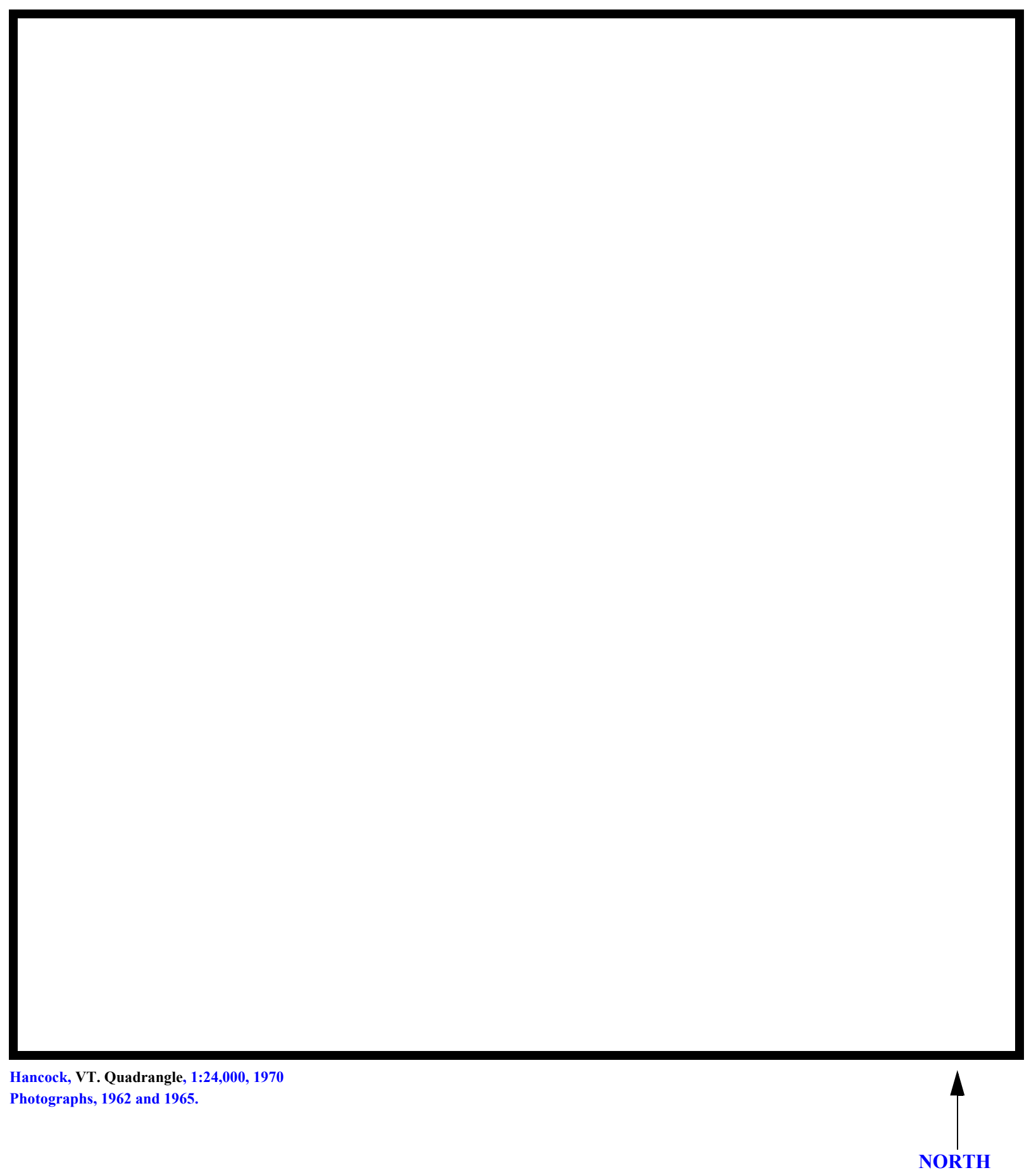

Figure 1. Location of study area on USGS 1:24,000 scale map. 
Figure 2. Location of study area on Vermont Agency of Transportation town highway map. 

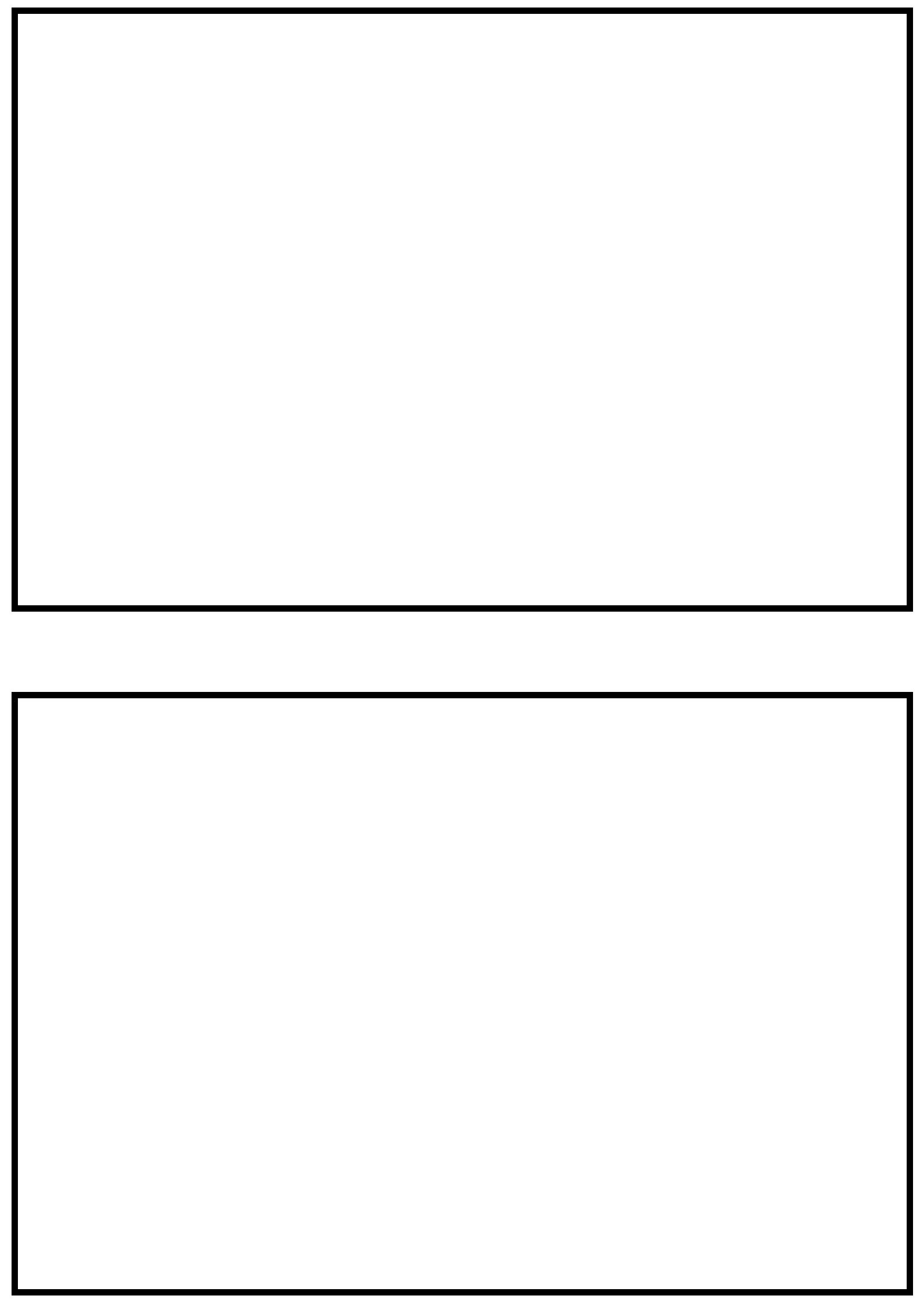

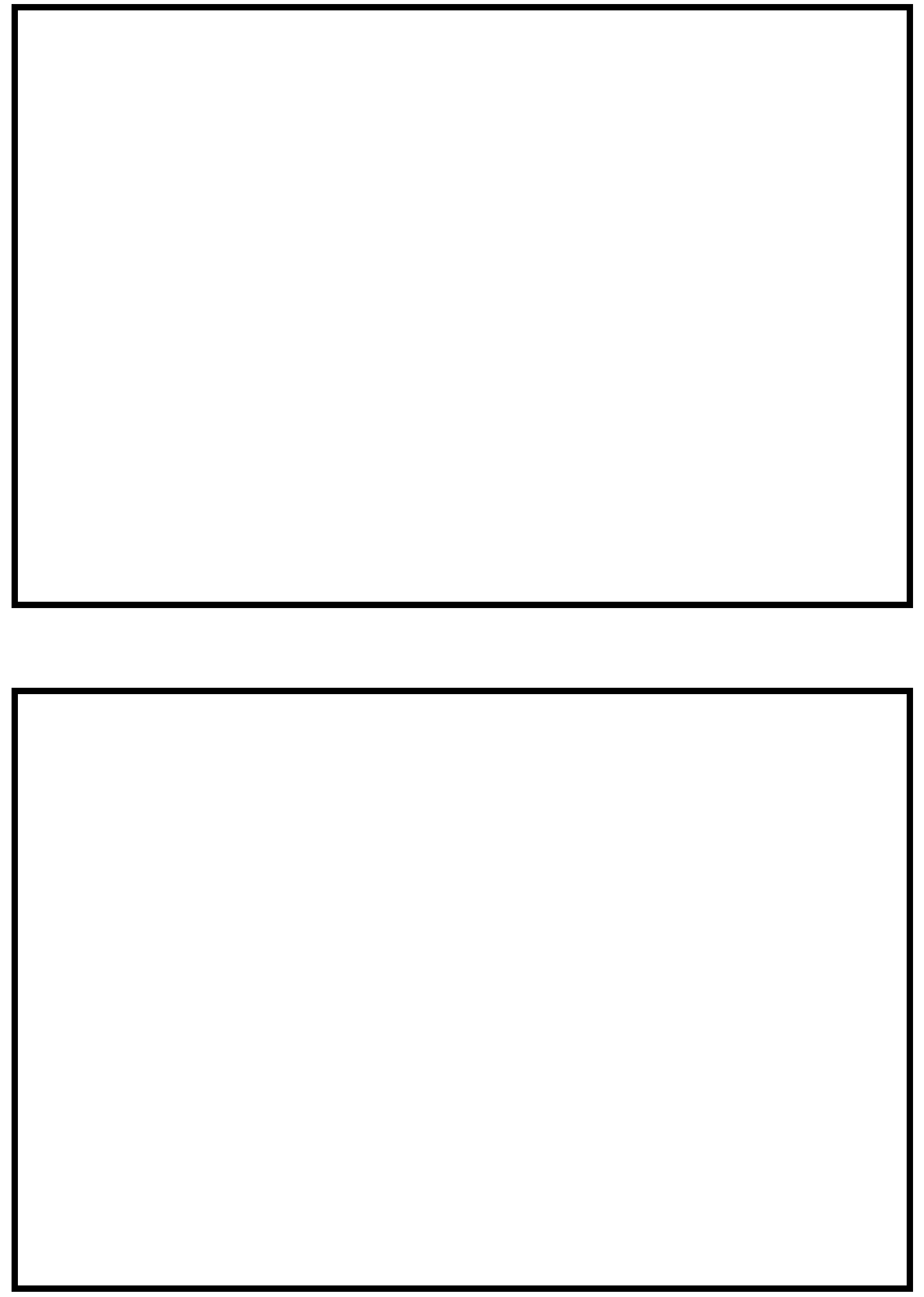


\section{LEVEL II SUMMARY}

\begin{tabular}{llllll} 
Structure Number & ROCHVT01000144 & \multirow{2}{*}{ Stream } & \multicolumn{2}{l}{ White River } & \\
& Road & VT 100 & District & 4 \\
County & Windsor & Roal & &
\end{tabular}

\section{Description of Bridge}

Bridge length $\frac{103}{f t}$ Bridge width $\stackrel{41.2}{f t}$ Max span length $\frac{101}{f t}$ Alignment of bridge to road (on curve or straight) Spill-through

Abutment type

Stone fill on abutment?

\section{Embankment type} Straight

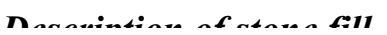
Yes

Dato af incnortion Type-2 protects the spill-through embankments of each abutment, the upstream left bank, and the downstream banks. The upstream right bank is protected with type-1 stone fill.

Abutments are vertical concrete walls with sloping

spill-through embankments in front of each wall.

\section{Y}

Is bridge skewed to flood flow according to Y Y survey?

Angle

There is a moderate channel bend in the upstream reach, A scour hole has developed along, the left bank upstream.

Debris accumulation on bridge at time of Level I or Level II site visit:

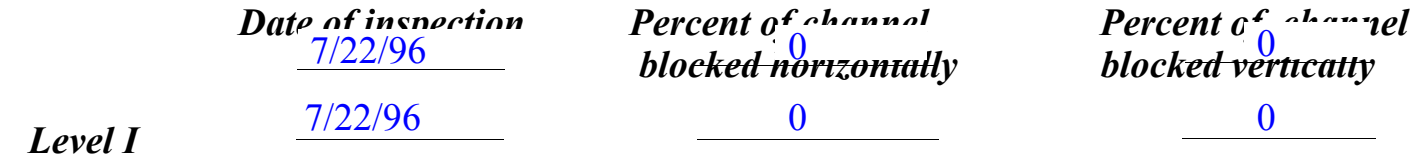

Level II

Moderate. There is some debris caught on boulders upstream and downstream. Some trees are present on laterally unstable banks.

Potential for debris

A scour hole has developed at the confluence of Marshs Brook with the White River 85 feet Doscriho anv, foaturos noar ar at the hridoo that mav, affort flow, (includo ahsorvation datol upstream noted on $7 / 22 / 96$. 


\section{Description of the Geomorphic Setting}

General topography The channel is located in a moderate relief valley setting with narrow, irregular flood plains and moderately sloping valley walls on both sides.

Geomorphic conditions at bridge site: downstream (DS), upstream (US)

Date of inspection $\quad$ 7/22/96

DS left: $\quad$ Slightly sloping channel bank to a narrow flood plain.

DS right: $\quad$ Slightly sloping channel bank to a narrow flood plain.

US left: $\quad$ Steep channel bank to a narrow overbank.

US right: $\quad$ Moderately sloping channel bank to a narrow flood plain.

\section{Description of the Channel}

\begin{tabular}{|c|c|c|c|}
\hline & 119 & & 4 \\
\hline Average top width & $\stackrel{\boldsymbol{f t}}{\text { Gravel / Cobbles }}$ & Average depth & Gravel/Sand \\
\hline
\end{tabular}

meandering with alluvial channel boundaries and wide point bäs.

$7 / 22 / 96$

Vegetative co 1 Young trees, shrubs and brush

DS left: $\quad$ Young trees, shrubs and brush

DS right: $\quad$ Short bushes, shrubs, brush and a few trees

US left: $\quad$ Short bushes, shrubs, brush and a few trees.

US right: $\quad \underline{\mathrm{N}}$

Do banks appear stable? On 7/22/96 a cut bank was noted on the upstream left bank and several wide, partially vegetated point bars were evident both upstream and downstream of this site.
date of observatton.

None evident on

7/22/96.

Describe any obstructions in channel and date of observation. 


\title{
Hydrology
}

Drainage area $\quad 68.9 \boldsymbol{m i}^{2}$

Percentage of drainage area in physiographic provinces: (approximate)

Physiographic province/section

New England / Green Mountain
Percent of drainage area 100

\begin{abstract}
Is drainage area considered rural or urban?
Rural

urbanization:

Describe any significant
\end{abstract}

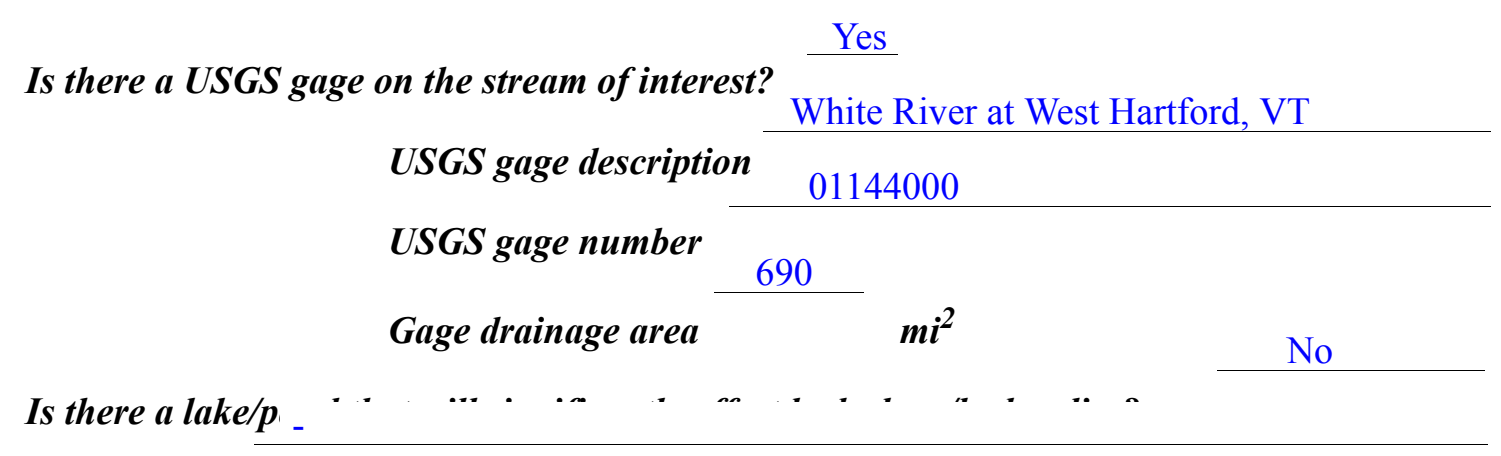

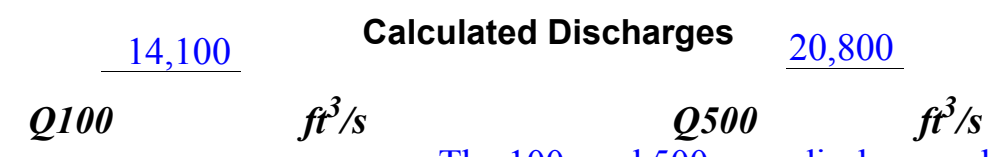

The 100- and 500-year discharges shown above are

based on a drainage area relationship [Qs $=\mathrm{Qf}(\mathrm{As} / \mathrm{Af}) \exp (0.67)$ ] applying the 100- and 500year discharges published for the upstream town line of Rochester on the White River (65 sq. mi.) in the Flood Insurance Study for the town (FEMA, 1991). These discharges were selected for the hydraulic analyses due to their central tendency with discharges computed by use of several empirical equations (Benson, 1962; FHWA, 1983; Johnson and Tasker, 1974; Potter, $1957 \mathrm{a} \& \mathrm{~b}$; Talbot, 1887) and those available from the VTAOT database (written communication, VTAOT, May, 1995). 


\section{Description of the Water-Surface Profile Model (WSPRO) Analysis}

Datum for WSPRO analysis (USGS survey, sea level, VTAOT plans)

USGS survey

Datum tie between USGS survey and VTAOT plans

Add 362.7 feet to the USGS

survey to obtain VTAOT plans' datum.

Description of reference marks used to determine USGS datum. $\quad$ RM2 is the center point

of a chiseled "X" on top of the downstream concrete curb, three feet from the right end (elev.

$497.26 \mathrm{ft}$, arbitrary survey datum). RM3 is a VTAOT brass tablet survey mark on top of the

upstream concrete curb, ten feet from the left end (elev. $500.22 \mathrm{ft}$, arbitrary survey datum).

\section{Cross-Sections Used in WSPRO Analysis}

\begin{tabular}{cccl}
\hline${ }^{1}$ Cross-section & $\begin{array}{c}\text { Section } \\
\text { Reference } \\
\text { Distance } \\
\text { (SRD) } \text { in feet }\end{array}$ & $\begin{array}{c}\text { 2 Cross-section } \\
\text { development }\end{array}$ & \multicolumn{1}{c}{ Comments } \\
\hline EXITX & -107 & 1 & Exit section \\
FULLV & 0 & 2 & $\begin{array}{l}\text { Downstream Full-valley } \\
\text { section (Templated from } \\
\text { EXITX) }\end{array}$ \\
BRIDG & 0 & 1 & $\begin{array}{l}\text { Bridge section } \\
\text { Road Grade section }\end{array}$ \\
RDWAY & 20 & 1 & $\begin{array}{l}\text { Modelled Approach sec- } \\
\text { tion (Templated from } \\
\text { APTEM) }\end{array}$ \\
APTEM & 139 & 2 & $\begin{array}{l}\text { Approach section as sur- } \\
\text { veyed (Used as a tem- } \\
\text { plate) }\end{array}$ \\
\hline
\end{tabular}

${ }^{1}$ For location of cross-sections see plan-view sketch included with Level I field form, Appendix E. For more detail on how cross-sections were developed see WSPRO input file. 


\section{Data and Assumptions Used in WSPRO Model}

Hydraulic analyses of the reach were done by use of the Federal Highway Administration's WSPRO step-backwater computer program (Shearman and others, 1986, and Shearman, 1990). The analyses reported herein reflect conditions existing at the site at the time of the study. Furthermore, in the development of the model it was necessary to assume no accumulation of debris or ice at the site. Results of the hydraulic model are presented in the Bridge Hydraulic Summary, Appendix B, and figure 7.

Channel roughness factors (Manning's " $n$ ") used in the hydraulic model were estimated using field inspections at each cross section following the general guidelines described by Arcement and Schneider (1989). Final adjustments to the values were made during the modelling of the reach. Channel " $\mathrm{n}$ " values for the reach ranged from 0.040 to 0.050 , and overbank " $\mathrm{n}$ " values ranged from 0.035 to 0.045 .

Normal depth at the exit section (EXITX) was assumed as the starting water surface. This depth was computed by use of the slope-conveyance method outlined in the user's manual for WSPRO (Shearman, 1990). The slope used was $0.00268 \mathrm{ft} / \mathrm{ft}$ which was estimated from topographic maps (U.S. Geological Survey, $1970 \mathrm{a \& b}$ ).

The surveyed approach section (APTEM) was moved along the approach channel slope $(0.0112 \mathrm{ft} / \mathrm{ft})$ to establish the modelled approach section (APPRO), one bridge length upstream

of the upstream face as recommended by Shearman and others (1986). This approach also provides a consistent method for determining scour variables. 


\section{Bridge Hydraulics Summary}

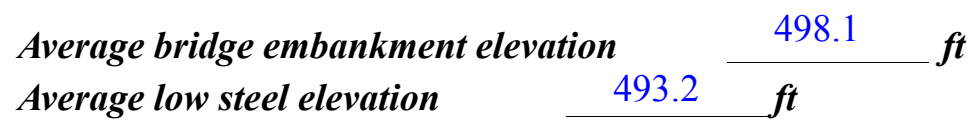

100-year discharge $\quad 14,100 \quad \mathrm{ft}^{3} / \mathrm{s}$

Water-surface elevation in bridge opening $\quad 489.6 \quad f t$

Road overtopping? ___ Yes Discharge over road _ $\quad \begin{array}{llll}6890 & \boldsymbol{f t}^{3} / \mathrm{s}\end{array}$

Area of flow in bridge opening $\quad 813 \quad \boldsymbol{f t}^{2}$

Average velocity in bridge opening $\quad \begin{array}{lll}8.9 & f t / s\end{array}$

$\begin{array}{lll}\text { Maximum WSPRO tube velocity at bridge } & 10.3 \mathrm{ft} / \mathrm{s}\end{array}$

Water-surface elevation at Approach section with bridge 491.8

$\begin{array}{lr}\text { Water-surface elevation at Approach section without bridge } & 489.9\end{array}$

Amount of backwater caused by bridge $\quad 1.9$ it

500-year discharge $\quad 20,800 \quad \mathrm{ft}^{3} / \mathrm{s}$

Water-surface elevation in bridge opening $\quad 490.7 \boldsymbol{f t}$

Road overtopping? ___ Yes Discharge over road __ 12,200 $\boldsymbol{f t}^{3} / \mathbf{s}$

Area of flow in bridge opening $\quad 916 \quad \mathrm{ft}^{2}$

Average velocity in bridge opening $\quad 9.4 \mathrm{ft} / \mathrm{s}$

Maximum WSPRO tube velocity at bridge 10.9 's

Water-surface elevation at Approach section with bridge 493.2

Water-surface elevation at Approach section without bridge $\quad 490.7$

Amount of backwater caused by bridge 2.5 .

Incipient overtopping discharge $\quad 3,750 \quad \mathrm{ft}^{3} / \mathrm{s}$

Water-surface elevation in bridge opening $486.6 \quad t$

Area of flow in bridge opening

Average velocity in bridge opening

Maximum WSPRO tube velocity at bridge

$539 \boldsymbol{f t}^{2}$

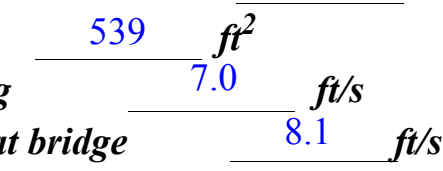

Water-surface elevation at Approach section with bridge

Water-surface elevation at Approach section without bridge

487.8

Amount of backwater caused by bridge

0.2 , $t$ 


\section{Scour Analysis Summary}

\section{Special Conditions or Assumptions Made in Scour Analysis}

Scour depths were computed using the general guidelines described in Hydraulic Engineering Circular 18 (Richardson and others, 1995). Scour depths were calculated assuming an infinite depth of erosive material and a homogeneous particle-size distribution. The results of the scour analysis are presented in tables 1 and 2 and a graph of the scour depths is presented in figure 8 .

Contraction scour was computed by use of the clear-water contraction scour equation (Richardson and others, 1995, p. 32, equation 20). For contraction scour computations, the average depth in the contracted section (AREA/TOPWIDTH) is subtracted from the depth of flow computed by the scour equation (Y2) to determine the actual amount of scour. In this case, there was no contraction scour computed for any of the modeled discharges.

Abutment scour for the 100- and 500-year discharges was computed by use of the HIRE equation (Richardson and others, 1995, p. 49, equation 29) because the HIRE equation is recommended when the length to depth ratio of the embankment blocking flow exceeds 25. Variables for the HIRE equation include the Froude number of the flow approaching the embankments, the length of the embankment blocking flow, and the depth of flow approaching the embankment less any roadway overtopping.

For the incipient over-topping discharge model, abutment scour was computed by use of the Froehlich abutment-scour equation (Richardson and others, 1995, p. 48, equation 28). The variables used by the Froehlich abutment-scour equation are defined the same as those defined for the HIRE abutment-scour equation.

Because the influence of scour processes on the spill-through embankment material is uncertain, the scour depth at the vertical concrete abutment walls is unknown. Therefore, the variables for the abutment scour equations applied were computed including the width of the spill-through embankments. The total scour depths were applied for the entire spillthrough embankment below the elevation at the toe of each embankment, as shown in figure 8. 


\section{Scour Results}

100-yr discharge 500-yrdischarge

Incipient

overtopping

Contraction scour:

(Scour depths in feet)

Main channel

Live-bed scour

Clear-water scour

Depth to armoring

Left overbank

Right overbank

Local scour:

Abutment scour

6.9

9.5

10.0

Left abutment

8.8-

$10.7-$

10.9-

Right abutment

Pier scour

Pier 1

Pier 2

Pier 3

Abutments:

Left abutment

Right abutment

Piers:

Pier 1

Pier 2

\section{Riprap Sizing}

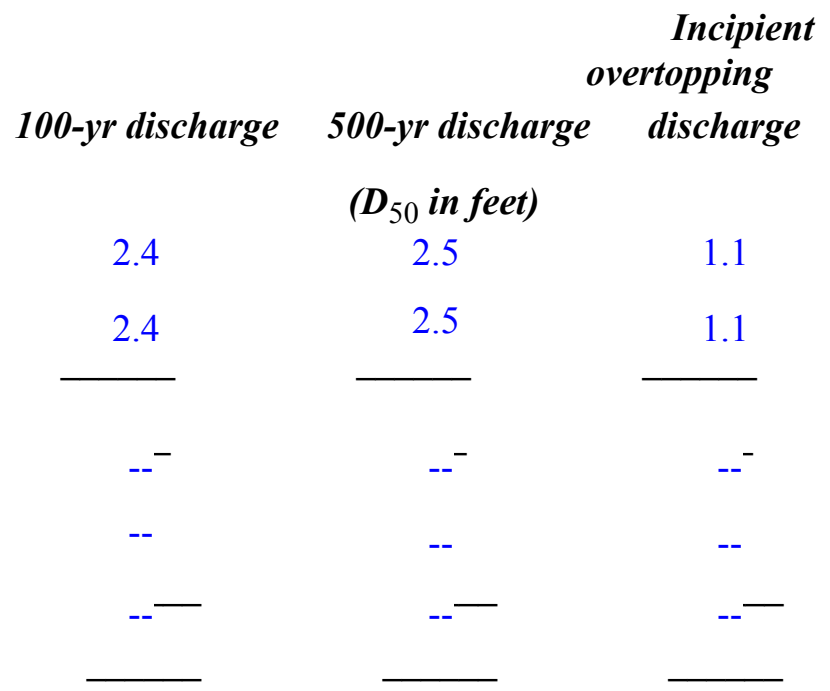




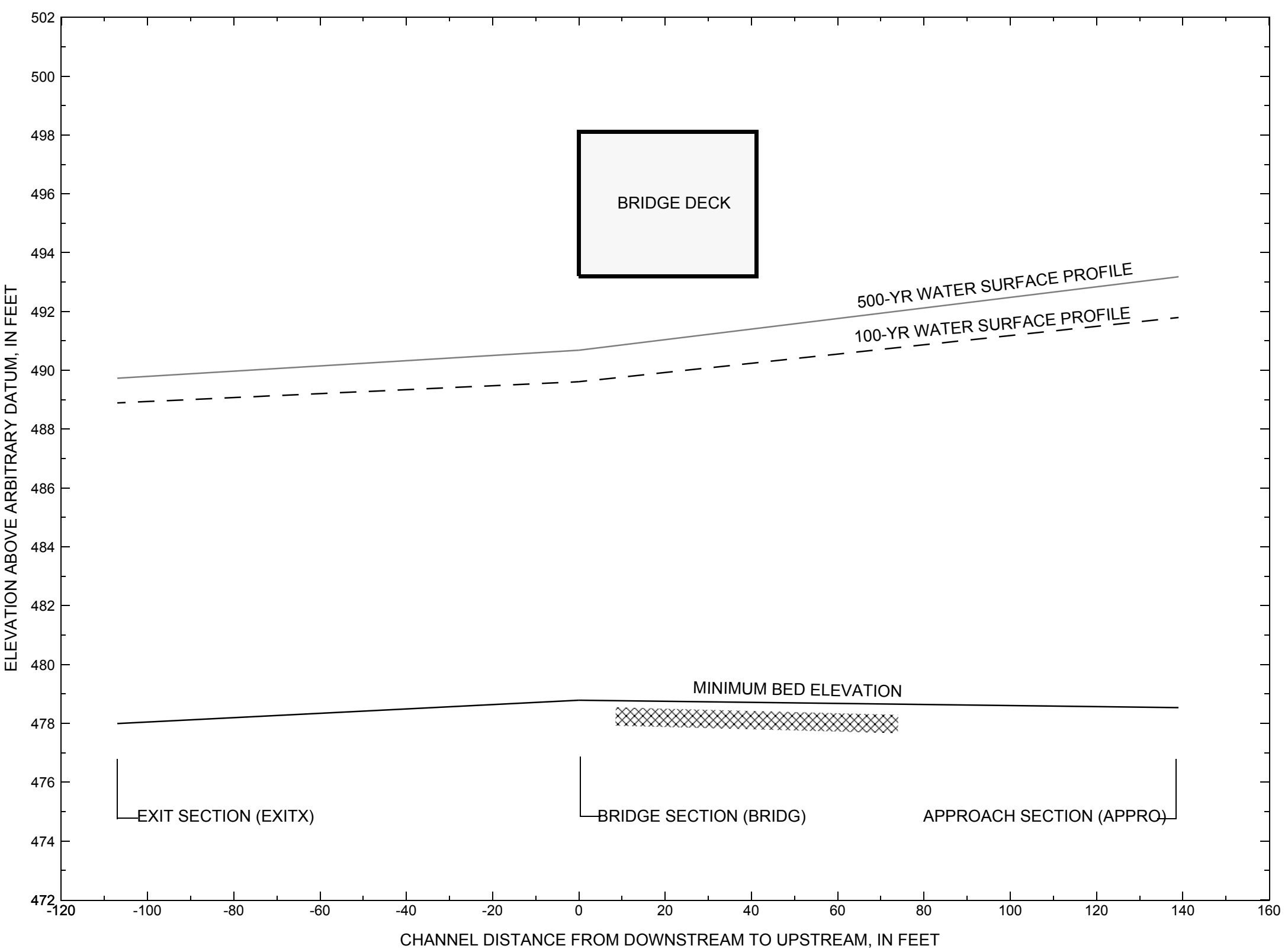

Figure 7. Water-surface profiles for the 100- and 500-yr discharges at structure ROCHVT01000144 on State Route 100, crossing White River, Rochester, Vermont. 


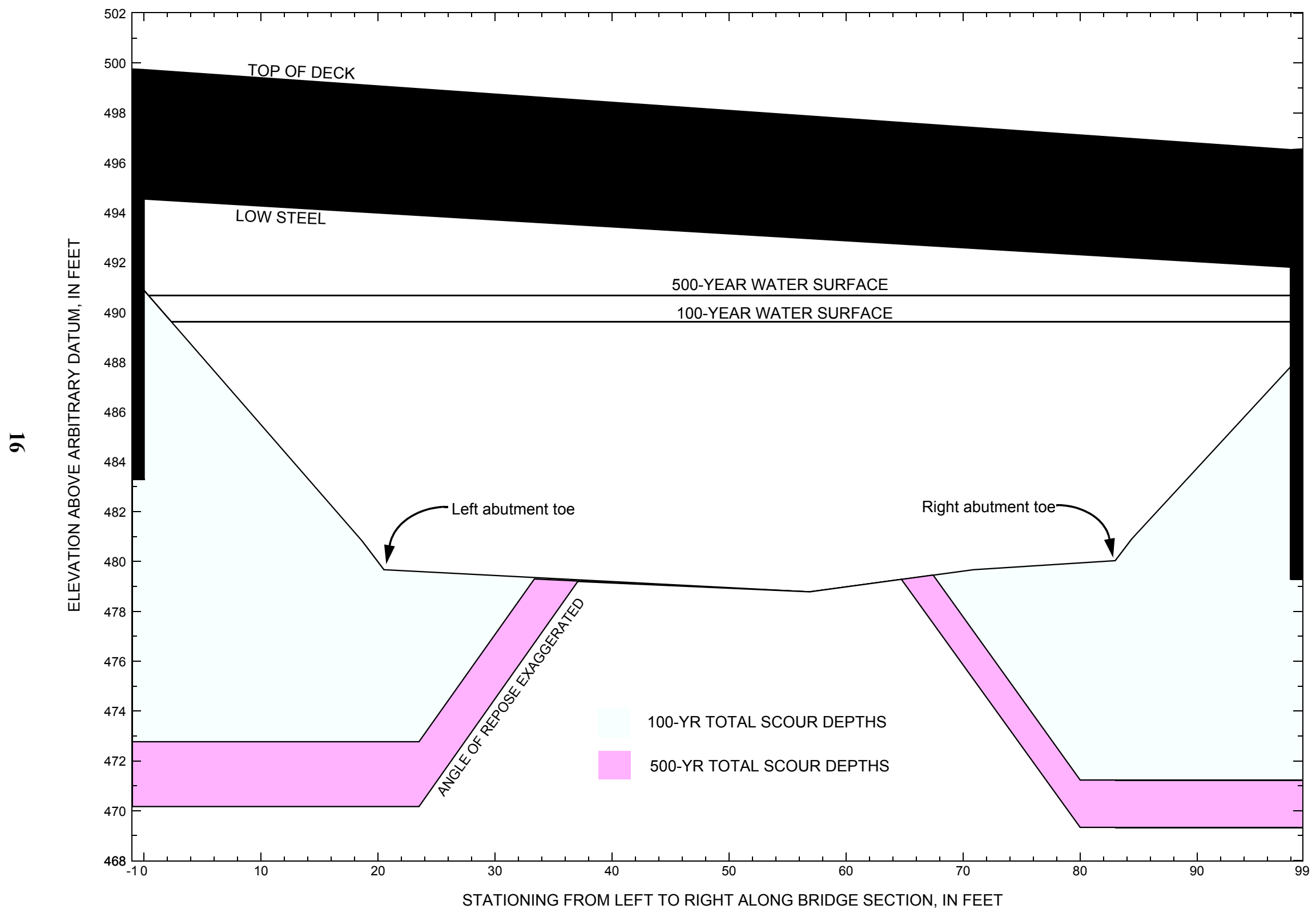

Figure 8. Scour elevations for the 100-yr and 500-yr discharges at structure ROCHVT01000144 on State Route 100, crossing the White River, Rochester, Vermont. 
Table 1. Remaining footing/pile depth at abutments for the 100-year discharge at structure ROCHVT01000144 on State Route 100, crossing the White River, Rochester, Vermont.

[VTAOT, Vermont Agency of Transportation; --,no data]

\begin{tabular}{|c|c|c|c|c|c|c|c|c|c|c|c|}
\hline Description & Station $^{1}$ & $\begin{array}{c}\text { VTAOT } \\
\text { Bridge seat } \\
\text { elevation } \\
\text { (feet) }\end{array}$ & $\begin{array}{l}\text { Surveyed } \\
\text { minimum } \\
\text { low-chord } \\
\text { elevation }{ }^{2} \\
\quad \text { (feet) }\end{array}$ & $\begin{array}{c}\text { Bottom of } \\
\text { footing } \\
\text { elevation } \\
\text { (feet) }\end{array}$ & $\begin{array}{c}\text { Channel } \\
\text { elevation at } \\
\text { abutment/ } \\
\text { pier }^{2} \\
\text { (feet) }\end{array}$ & $\begin{array}{l}\text { Contraction } \\
\text { scour depth } \\
\text { (feet) }\end{array}$ & $\begin{array}{l}\text { Abutment } \\
\text { scour } \\
\text { depth } \\
\text { (feet) }\end{array}$ & $\begin{array}{l}\text { Pier } \\
\text { scour } \\
\text { depth } \\
\text { (feet) }\end{array}$ & $\begin{array}{l}\text { Depth of } \\
\text { total scour } \\
\text { (feet) }\end{array}$ & $\begin{array}{c}\text { Elevation of } \\
\text { scour }^{2} \\
\text { (feet) }\end{array}$ & $\begin{array}{c}\text { Remaining } \\
\text { footing/pile } \\
\text { depth } \\
\text { (feet) }\end{array}$ \\
\hline \multicolumn{12}{|c|}{100 -yr. discharge is 14,100 cubic-feet per second } \\
\hline Left abutment & 0.0 & 856.9 & 494.3 & 483.3 & 490.9 & -- & -- & -- & -- & -- & -10.5 \\
\hline Left abutment toe & 20.5 & -- & -- & -- & 479.7 & 0.0 & 6.9 & -- & 6.9 & 472.8 & -- \\
\hline Right abutment toe & 83.0 & -- & -- & -- & 480.0 & 0.0 & 8.8 & -- & 8.8 & 471.2 & -- \\
\hline Right abutment & 98.0 & 854.3 & 491.5 & 479.3 & 487.8 & -- & -- & -- & -- & -- & -8.1 \\
\hline
\end{tabular}

1.Measured along the face of the most constricting side of the bridge.

2.Arbitrary datum for this study.

Table 2. Remaining footing/pile depth at abutments for the 500-year discharge at structure ROCHVT01000144 on State Route 100, crossing the White River, Rochester, Vermont.

[VTAOT, Vermont Agency of Transportation; --, no data]

\begin{tabular}{|c|c|c|c|c|c|c|c|c|c|c|c|}
\hline Description & Station $^{1}$ & $\begin{array}{c}\text { VTAOT } \\
\text { Bridge seat } \\
\text { elevation } \\
\text { (feet) }\end{array}$ & $\begin{array}{l}\text { Surveyed } \\
\text { minimum } \\
\text { low-chord } \\
\text { elevation } \\
\text { (feet) }\end{array}$ & $\begin{array}{c}\text { Bottom of } \\
\text { footing } \\
\text { elevation } \\
\text { (feet) }\end{array}$ & $\begin{array}{l}\text { Channel } \\
\text { elevation at } \\
\text { abutment/ } \\
\text { pier }^{2} \\
\text { (feet) }\end{array}$ & $\begin{array}{c}\text { Contraction } \\
\text { scour depth } \\
\text { (feet) }\end{array}$ & $\begin{array}{l}\text { Abutment } \\
\text { scour } \\
\text { depth } \\
\text { (feet) }\end{array}$ & $\begin{array}{l}\text { Pier } \\
\text { scour } \\
\text { depth } \\
\text { (feet) }\end{array}$ & $\begin{array}{l}\text { Depth of } \\
\text { total scour } \\
\text { (feet) }\end{array}$ & $\begin{array}{c}\text { Elevation of } \\
\text { scour }^{2} \\
\text { (feet) }\end{array}$ & $\begin{array}{c}\text { Remaining } \\
\text { footing/pile } \\
\text { depth } \\
\text { (feet) }\end{array}$ \\
\hline \multicolumn{12}{|c|}{500 -yr. discharge is 20,800 cubic-feet per second } \\
\hline Left abutment & 0.0 & 856.9 & 494.3 & 483.3 & 490.9 & -- & -- & -- & -- & -- & -13.1 \\
\hline Left abutment toe & 20.5 & -- & -- & -- & 479.7 & 0.0 & 9.5 & -- & 9.5 & 470.2 & -- \\
\hline Right abutment toe & 83.0 & -- & -- & -- & 480.0 & 0.0 & 10.7 & -- & 10.7 & 469.3 & -- \\
\hline Right abutment & 98.0 & 854.3 & 491.5 & 479.3 & 487.8 & -- & -- & -- & -- & -- & -10.0 \\
\hline
\end{tabular}

1.Measured along the face of the most constricting side of the bridge.

2.Arbitrary datum for this study. 


\section{SELECTED REFERENCES}

Arcement, G.J., Jr., and Schneider, V.R., 1989, Guide for selecting Manning's roughness coefficients for natural channels and flood plains: U.S. Geological Survey Water-Supply Paper 2339, 38 p.

Barnes, H.H., Jr., 1967, Roughness characteristics of natural channels: U.S. Geological Survey Water-Supply Paper 1849,213 p.

Benson, M. A., 1962, Factors Influencing the Occurrence of Floods in a Humid Region of Diverse Terrain: U.S. Geological Survey WaterSupply Paper 1580-B, 64 p.

Brown, S.A. and Clyde, E.S., 1989, Design of riprap revetment: Federal Highway Administration Hydraulic Engineering Circular No. 11, Publication FHWA-IP-89-016, 156 p.

Federal Highway Administration, 1983, Runoff estimates for small watersheds and development of sound design: Federal Highway Administration Report FHWA-RD-77-158

Federal Emergency Management Agency, 1991, Flood Insurance Study, Town of Rochester, Windsor County, Vermont: Washington, D.C., August 1991.

Froehlich, D.C., 1989, Local scour at bridge abutments in Ports, M.A., ed., Hydraulic Engineering--Proceedings of the 1989 National Conference on Hydraulic Engineering: New York, American Society of Civil Engineers, p. 13-18.

Hayes, D.C.,1993, Site selection and collection of bridge-scour data in Delaware, Maryland, and Virginia: U.S. Geological Survey WaterResources Investigation Report 93-4017, 23 p.

Interagency Advisory Committee on Water Data, 1982, Guidelines for determining flood flow frequency: U.S. Geological Survey, Bulletin 17B of the Hydrology Subcommittee, $190 \mathrm{p}$.

Johnson, C.G. and Tasker, G.D.,1974, Progress report on flood magnitude and frequency of Vermont streams: U.S. Geological Survey OpenFile Report 74-130, 37 p.

Lagasse, P.F., Schall, J.D., Johnson, F., Richardson, E.V., Chang, F., 1995, Stream Stability at Highway Structures: Federal Highway Administration Hydraulic Engineering Circular No. 20, Publication FHWA-IP-90-014, 144 p.

Laursen, E.M., 1960, Scour at bridge crossings: Journal of the Hydraulics Division, American Society of Civil Engineers, v. 86, no. HY2, p. 39-53.

Potter, W. D., 1957a, Peak rates of runoff in the Adirondack, White Mountains, and Maine woods area, Bureau of Public Roads

Potter, W. D., 1957b, Peak rates of runoff in the New England Hill and Lowland area, Bureau of Public Roads

Richardson, E.V. and Davis, S.R., 1995, Evaluating scour at bridges: Federal Highway Administration Hydraulic Engineering Circular No. 18, Publication FHWA-IP-90-017, 204 p.

Richardson, E.V., Simons, D.B., and Julien, P.Y., 1990, Highways in the river environment: Federal Highway Administration Publication FHWA-HI-90-016.

Ritter, D.F., 1984, Process Geomorphology: W.C. Brown Co., Debuque, Iowa, 603 p.

Shearman, J.O., 1990, User's manual for WSPRO--a computer model for water surface profile computations: Federal Highway Administration Publication FHWA-IP-89-027, 187 p.

Shearman, J.O., Kirby, W.H., Schneider, V.R., and Flippo, H.N., 1986, Bridge waterways analysis model; research report: Federal Highway Administration Publication FHWA-RD-86-108, 112 p.

Talbot, A.N., 1887, The determination of water-way for bridges and culverts.

U.S. Department of Transportation, 1993, Stream stability and scour at highway bridges, Participant Workbook: Federal Highway Administration Publication FHWA HI-91-011.

U.S. Geological Survey, 1970a, Hancock, Vermont 7.5 Minute Series quadrangle map: U.S. Geological Survey Topographic Maps, Aerial Photographs, 1962 and 1965; Contour interval, 20 feet; Scale 1:24,000.

U.S. Geological Survey, 1970b, Rochester, Vermont 7.5 Minute Series quadrangle map: U.S. Geological Survey Topographic Maps, Aerial Photographs, 1962 and 1965; Photorevised, 1988, Contour interval, 20 feet; Scale 1:24,000. 


\section{APPENDIX A: \\ WSPRO INPUT FILE}




\section{WSPRO INPUT FILE}

GR

GR

GR

GR

GR

GR

*

$\mathrm{N}$

SA

*

*

XS

*

*

BR

GR

GR

GR

*

*

$\mathrm{CD}$

$\mathrm{N}$

*

*

*

$\mathrm{XR}$

GR

GR

GR

$\mathrm{XT}$

GR

GR

GR

GR

GR

GR

GR

GR

*

AS

GT

$\mathrm{N}$
U.S. Geological Survey WSPRO Input File roch144.wsp Hydraulic analysis for structure ROCHVT01000144 Date: 23-OCT-96 State Route 100 Crossing the White River, Rochester, VT

EMB

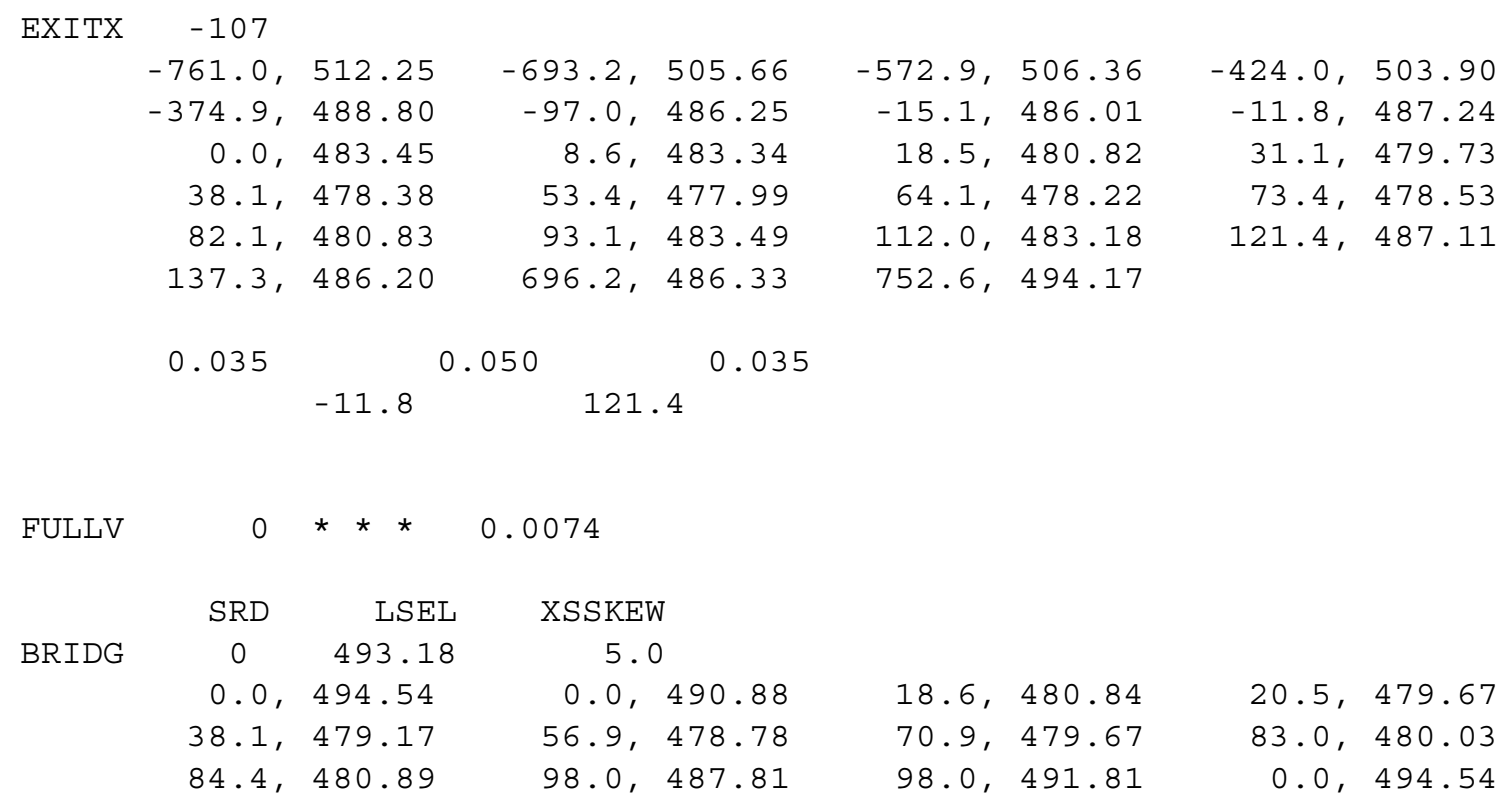

$\begin{array}{ll}18.6, & 480.84 \\ 70.9, & 479.67\end{array}$

$98.0,491.81$

$20.5,479.67$

$83.0,480.03$

$0.0,494.54$

No embankment slope points surveyed. EMBSS was estimated using average spill-through embankment slope angle plus 10 degrees based on discussion with field personnel, EW 10/24/96.

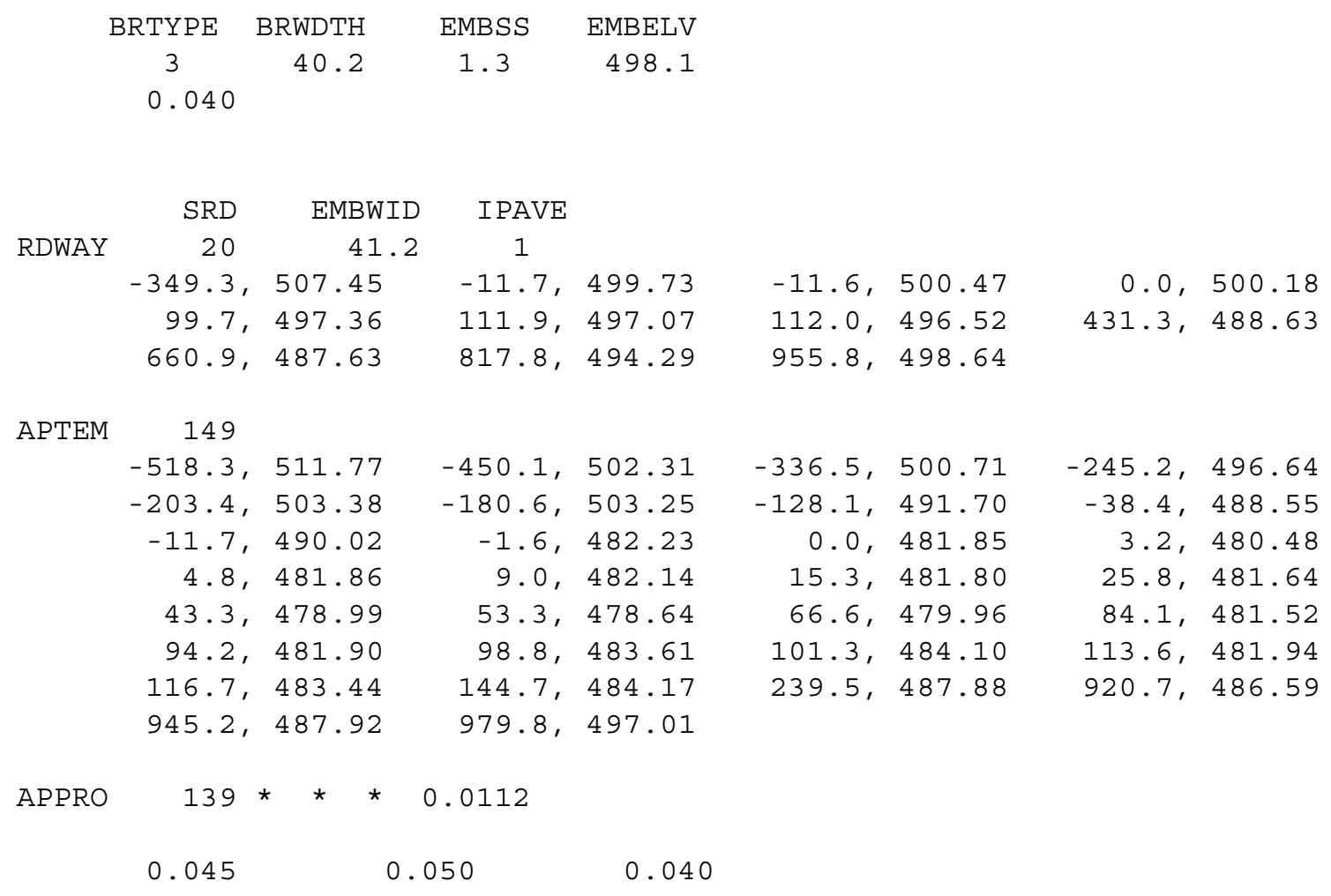


WSPRO INPUT FILE (continued)

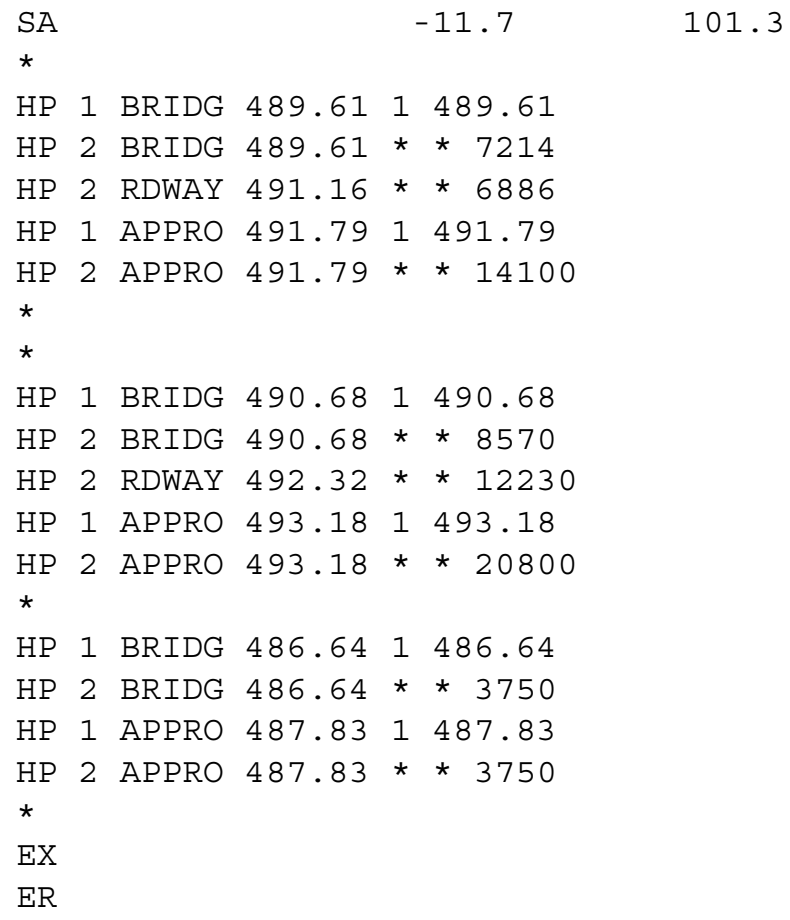




\section{APPENDIX B: \\ WSPRO OUTPUT FILE}


WSPRO OUTPUT FILE

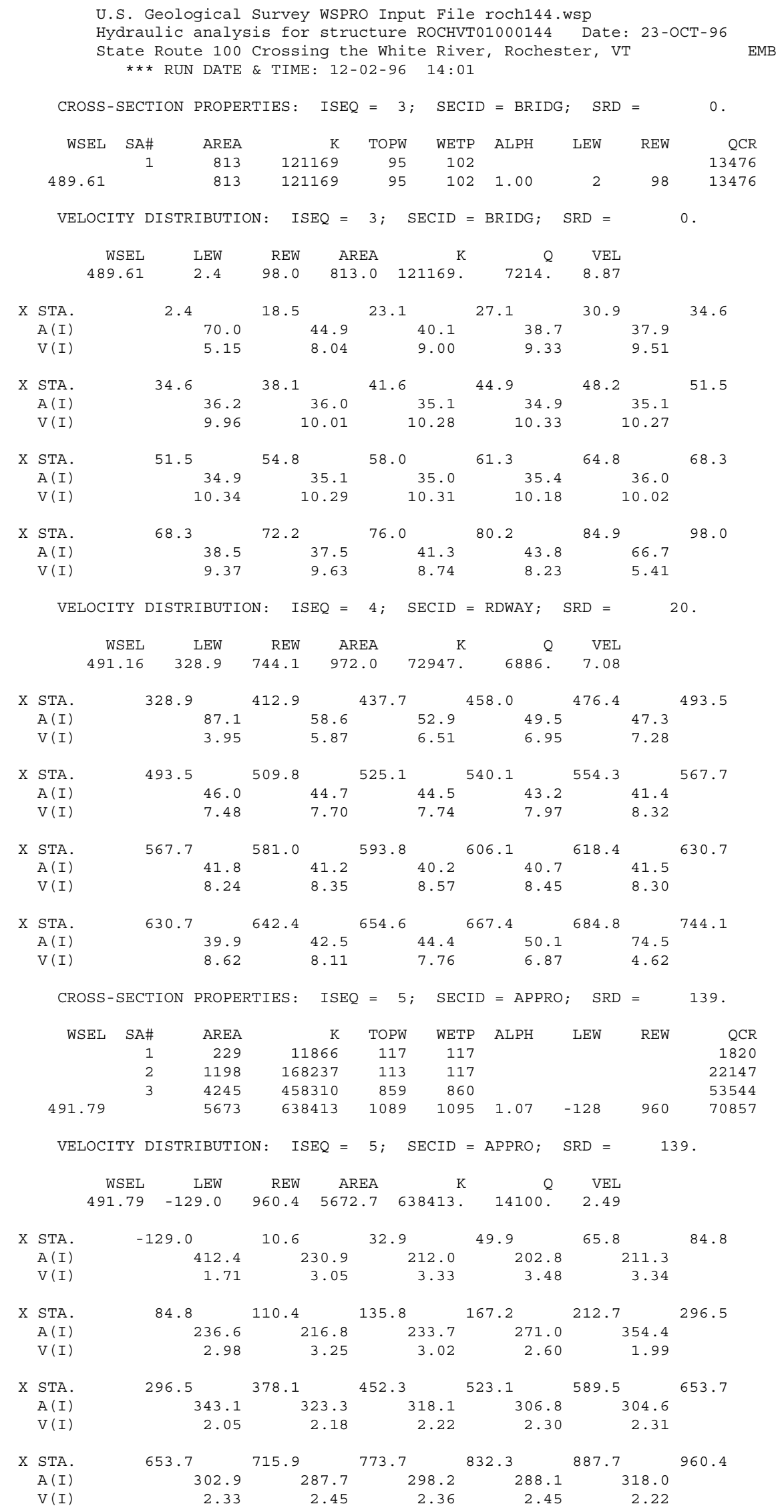


WSPRO OUTPUT FILE (continued)

\author{
U.S. Geological Survey WSPRO Input File roch144.wsp \\ Hydraulic analysis for structure ROCHVT01000144 Date: 23-OCT-96 \\ State Route 100 Crossing the white River, Rochester, VT EMB \\ *** RUN DATE \& TIME: $12-02-96$ 14:01 \\ CROSS-SECTION PROPERTIES: ISEQ $=3 ;$ SECID $=$ BRIDG $; \quad$ SRD $=0$. \\ $\begin{array}{rrrrrrrr}\text { WSEL SA\# } & \text { AREA } & \mathrm{K} & \text { TOPW } & \text { WETP } & \text { ALPH } & \text { LEW } & \text { REW }\end{array}$ \\ $\begin{array}{lllllllll}490.68 & 1 & 916 & 144690 & 97 & 105 & & & 15953 \\ & 916 & 144690 & 97 & 105 & 1.00 & 0 & 98 & 15953\end{array}$ \\ VELOCITY DISTRIBUTION: ISEQ $=3 ; \operatorname{SECID~}=$ BRIDG; $\quad \mathrm{SRD}=\quad 0$.

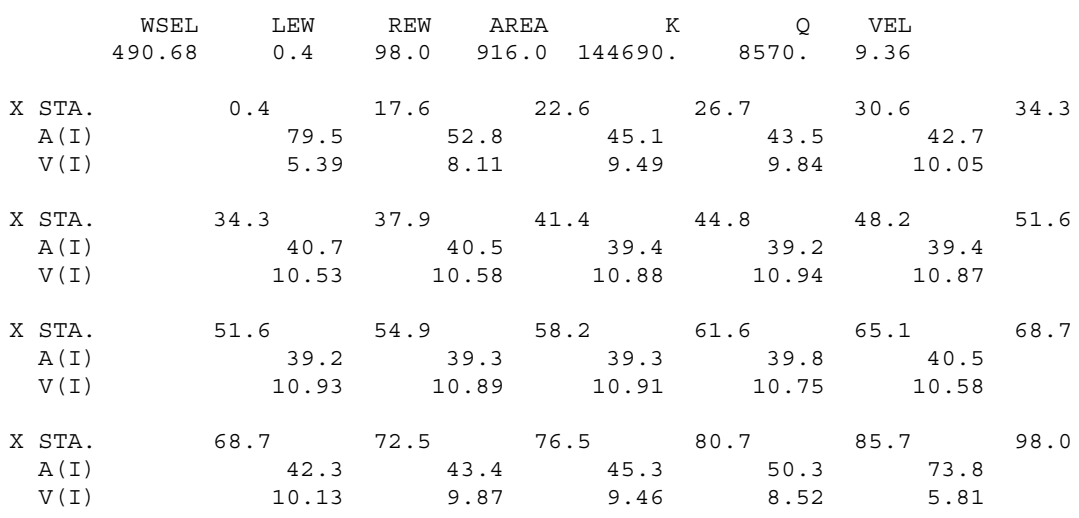 \\ VELOCITY DISTRIBUTION: ISEQ $=4 ; \operatorname{SECID}=$ RDWAY $; \quad \operatorname{SRD}=20$.

\begin{tabular}{|c|c|c|c|c|c|c|c|c|c|c|c|c|}
\hline & & ISEL & LEW & REW & $A R E$ & $\mathrm{EA}$ & & $\mathrm{K}$ & Q & VEL & & \\
\hline & 492 & .32 & 32.0 & 771.4 & 1496. & .6 & 134 & 206 & 12230. & 8.17 & & \\
\hline $\mathrm{x}$ & STA. & 282.0 & & 387.6 & & 418. & & 441 & 1.0 & 461.1 & & 479.8 \\
\hline & $A(I)$ & & 138.0 & & 93.2 & & & 0.2 & 76.0 & & 72.2 & \\
\hline & $V(I)$ & & 4.43 & & 6.56 & & & .63 & 8.04 & & 8.47 & \\
\hline $\mathrm{X}$ & STA. & 479.8 & & 497.5 & & 514. & & 530 & 0.2 & 546.0 & & 560.9 \\
\hline & $A(I)$ & & 69.9 & & 66.5 & & & 5.7 & 65.7 & & 62.7 & \\
\hline & $\mathrm{V}(\mathrm{I})$ & & 8.75 & & 9.19 & & & .31 & 9.30 & & 9.75 & \\
\hline $\mathrm{X}$ & STA. & 560.9 & & 575.6 & & 589. & & 604 & 4.0 & 617.7 & & 631.5 \\
\hline & $A(I)$ & & 63.0 & & 62.0 & & & 2.4 & 61.6 & & 62.6 & \\
\hline & $V(I)$ & & 9.70 & & 9.86 & & & .80 & 9.93 & & 9.77 & \\
\hline $\mathrm{x}$ & STA. & 631.5 & & 645.4 & & 659. & & 674 & 4.8 & 696.6 & & 771.4 \\
\hline & $A(I)$ & & 63.7 & & 64.4 & & & 9.0 & 79.1 & & 18.9 & \\
\hline & $V(I)$ & & 9.60 & & 9.50 & & & .87 & 7.73 & & 5.14 & \\
\hline & CROSS & SECTION & PROPER & RTIES: & ISEQ & $=$ & $5 ;$ & SECID & $=\mathrm{APPRO} ;$ & SRD & $=$ & 139. \\
\hline & WSEL & SA\# & AREA & & $\mathrm{K}$ & TOP & & WETP & $\mathrm{ALPH}$ & LEW & REW & QCR \\
\hline & & 1 & 397 & & 8548 & 12 & 24 & 124 & & & & 4034 \\
\hline & & 2 & 1356 & 206 & 6569 & 11 & 13 & 117 & & & & 26641 \\
\hline & & 3 & 5443 & 690 & 0605 & 86 & 54 & 866 & & & & 77499 \\
\hline & 493.18 & & 7195 & 925 & 5723 & 110 & & 1107 & 1.05 & -134 & 966 & 101940 \\
\hline
\end{tabular} \\ VELOCITY DISTRIBUTION: ISEQ $=5 ;$ SECID $=$ APPRO; $\quad$ SRD $=139$.

\begin{tabular}{|c|c|c|c|c|c|c|c|}
\hline & & WSEL & REW & REA & $Q$ & VEL & \\
\hline & & 493.18 & 965.6 & 925723 . & 20800 . & 2.89 & \\
\hline \multirow[t]{3}{*}{$\mathrm{x}$} & STA. & -135.3 & 5.8 & 32.1 & 52.2 & 72.6 & 98.0 \\
\hline & $A(I)$ & 556.5 & 305.9 & 278.6 & 281.4 & 298.4 & \\
\hline & $V(I)$ & 1.87 & 3.40 & 3.73 & 3.70 & 3.49 & \\
\hline \multirow[t]{3}{*}{$\mathrm{x}$} & STA. & 98.0 & 126.7 & 158.8 & 200.6 & 269.6 & 343.1 \\
\hline & $A(I)$ & 288.1 & 293.3 & 323.7 & 404.1 & 407.1 & \\
\hline & $V(I)$ & 3.61 & 3.55 & 3.21 & 2.57 & 2.55 & \\
\hline \multirow[t]{3}{*}{$\mathrm{X}$} & STA. & 343.1 & 413.4 & 479.5 & 543.8 & 605.2 & 665.7 \\
\hline & $A(I)$ & 399.1 & 383.4 & 381.0 & 371.4 & 372.7 & \\
\hline & $V(I)$ & 2.61 & 2.71 & 2.73 & 2.80 & 2.79 & \\
\hline \multirow[t]{3}{*}{$\mathrm{x}$} & STA. & 665.7 & 723.6 & 780.0 & 835.8 & 890.3 & 965.6 \\
\hline & $A(I)$ & 363.7 & 359.4 & 362.1 & 359.3 & 405.9 & \\
\hline & $V(I)$ & 2.86 & 2.89 & 2.87 & 2.89 & 2.56 & \\
\hline
\end{tabular}


WSPRO OUTPUT FILE (continued)

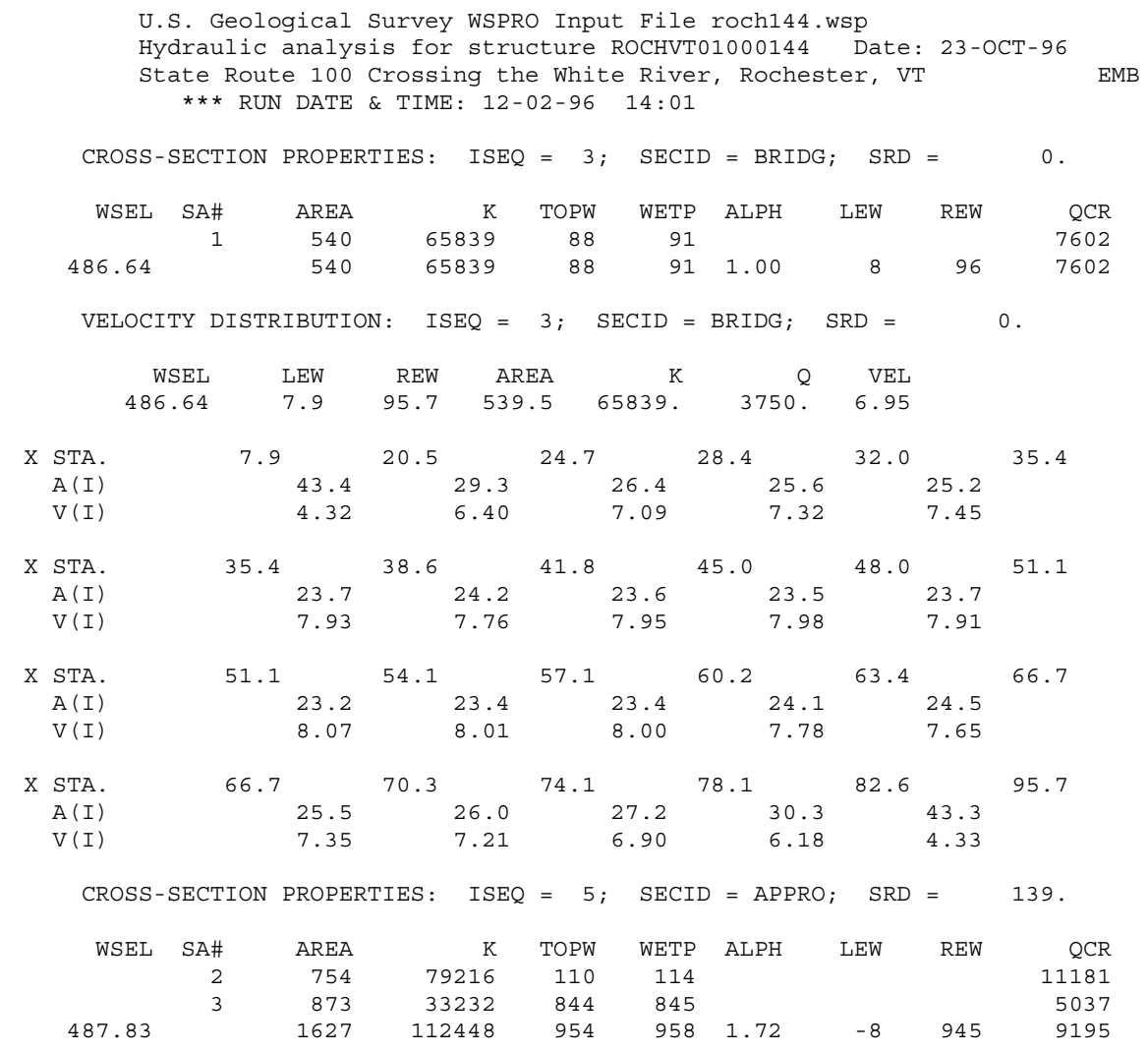

VELOCITY DISTRIBUTION: ISEQ = 5; SECID = APPRO; $\quad$ SRD $=139$.

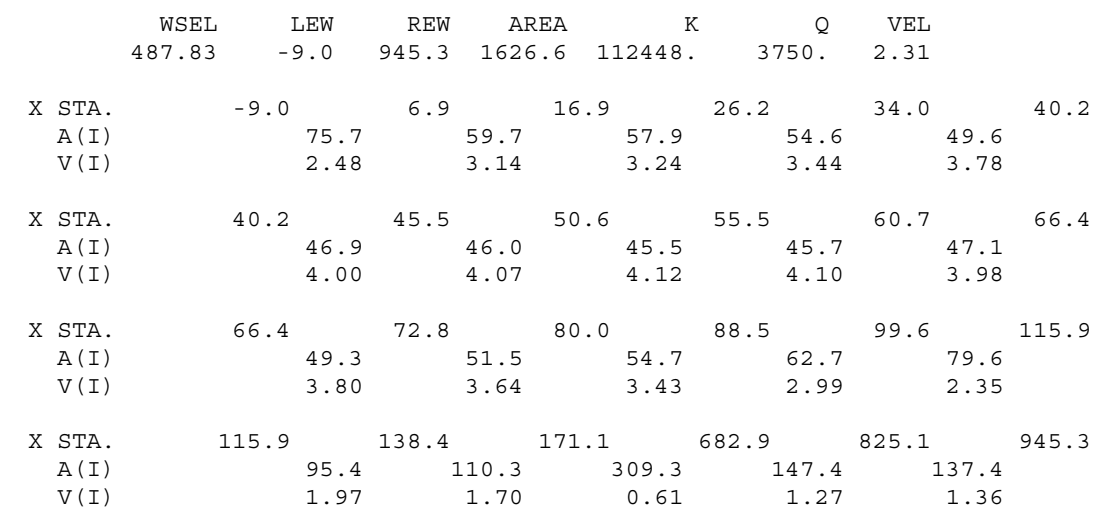


WSPRO OUTPUT FILE (continued)

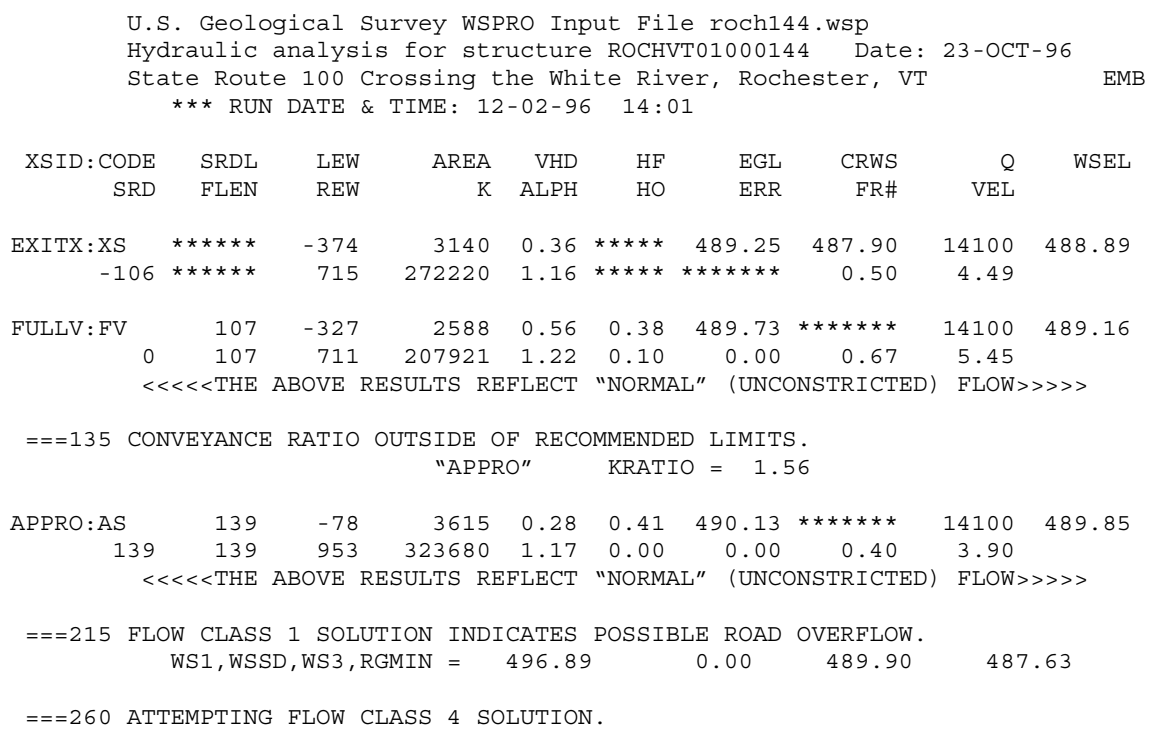

FIRST USER DEFINED TABLE.

\begin{tabular}{|c|c|c|c|c|c|c|c|c|}
\hline XSID : CODE & SRD & LEW & REW & $\mathrm{Q}$ & $\mathrm{K}$ & AREA & VEL & WSEL \\
\hline EXITX:XS & -107. & -375. & 715. & 14100 . & 272220 . & 3140. & 4.49 & 488.89 \\
\hline FULLV : FV & 0 & -328 & 711. & 14100 . & 207921. & 2588 . & 5.45 & 489.16 \\
\hline BRIDG : BR & 0 & 2 . & 98. & 7214 & 121172. & 813 & 8.87 & 489.61 \\
\hline RDWAY : RG & $20 . *$ & $* \star * \star * *$ & 0 . & 6886 & 0 & $* * * * * *$ & 1.00 & 491.16 \\
\hline APPRO : AS & 139. & -129. & 960. & 14100 . & 639003. & 5676. & 2.48 & 491.79 \\
\hline XSID: CODE & XLKQ & $\mathrm{XRKQ}$ & & & & & & \\
\hline APPRO : AS & 109. & 205. & 95994 & & & & & \\
\hline
\end{tabular}

SECOND USER DEFINED TABLE.

$\begin{array}{lcrrrrrrrr}\text { XSID : CODE } & \text { CRWS } & \text { FR\# } & \text { YMIN } & \text { YMAX } & \text { HF } & \text { HO } & \text { VHD } & \text { EGL } & \text { WSEL } \\ \text { EXITX:XS } & 487.90 & 0.50 & 477.99 & 512.25 * * * * * * * * * * & 0.36 & 489.25 & 488.89 \\ \text { FULLV : FV } & * * * * * * * * & 0.67 & 478.78 & 513.04 & 0.38 & 0.10 & 0.56 & 489.73 & 489.16 \\ \text { BRIDG : BR } & 486.40 & 0.64 & 478.78 & 494.54 & 0.47 & 1.66 & 1.76 & 491.37 & 489.61 \\ \text { RDWAY : RG } & * * * * * * * * * * * * * * * & 487.63 & 507.45 & 0.05 * * * * * * & 0.10 & 491.86 & 491.16 \\ \text { APPRO : AS } & 488.47 & 0.20 & 478.53 & 511.66 & 0.35 & 0.17 & 0.10 & 491.90 & 491.79\end{array}$


WSPRO OUTPUT FILE (continued)

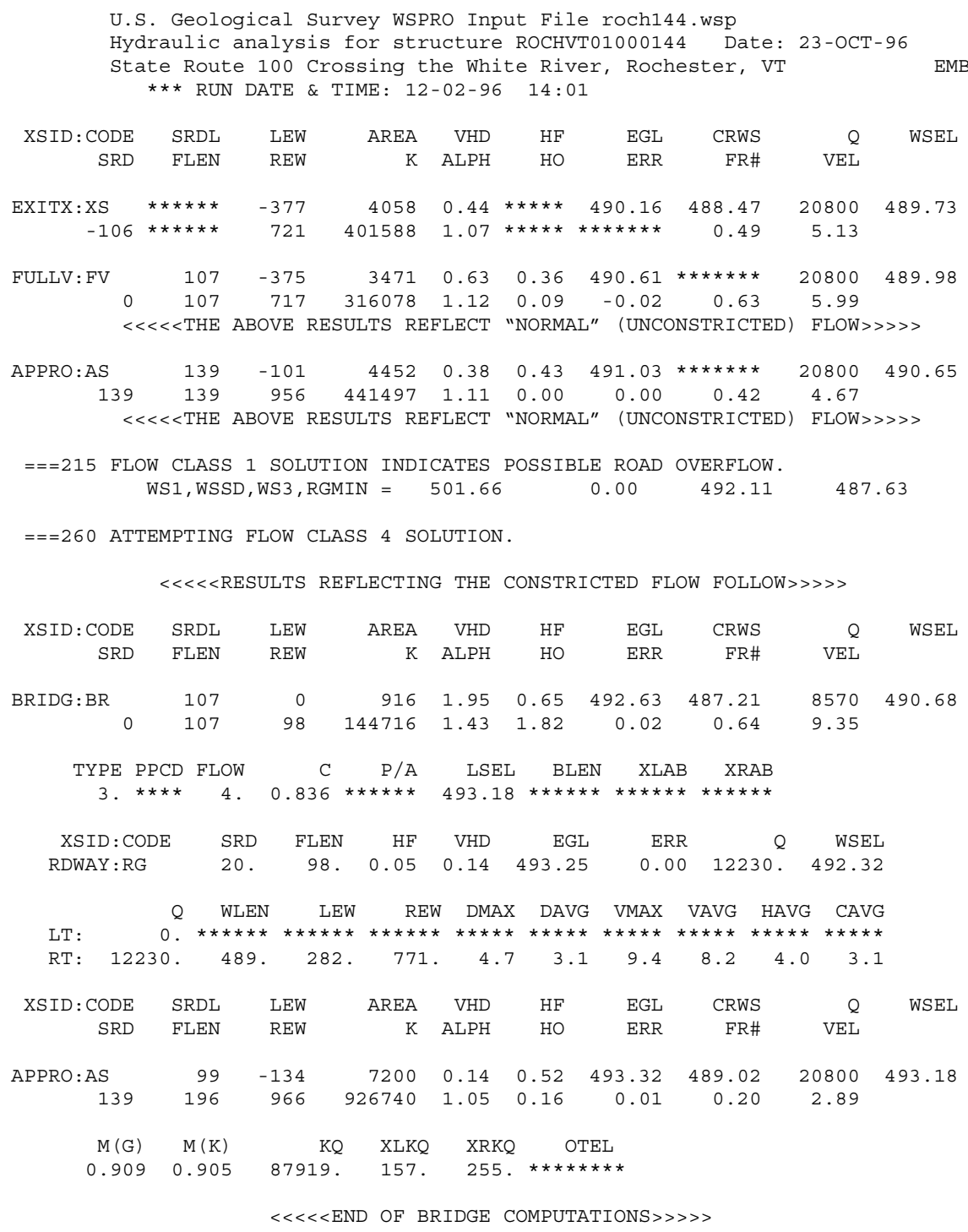

FIRST USER DEFINED TABLE.

\begin{tabular}{|c|c|c|c|c|c|c|c|c|}
\hline XSID : CODE & SRD & LEW & REW & Q & $\mathrm{K}$ & AREA & VEL & WSEL \\
\hline EXITX:XS & -107. & -378 & 721. & 20800 . & 401588. & 4058 . & 5.13 & 489.73 \\
\hline FULLV : FV & 0 & -376 . & 717. & 20800 . & 316078 . & 3471 . & 5.99 & 489.98 \\
\hline BRIDG : BR & 0 . & 0 & 98. & 8570 & 144716 . & 916. & 9.35 & 490.68 \\
\hline RDWAY : RG & 20 & $\star \star \star \star \star *$ & 0 & 12230 . & 0 & $* \star \star * \star *$ & 1.00 & 492.32 \\
\hline APPRO: AS & 139. & -135. & 966. & 20800 . & 926740. & 7200 . & 2.89 & 493.18 \\
\hline XSID : CODE & XLKQ & XRKQ & \multicolumn{2}{|c|}{ KQ } & & & & \\
\hline APPRO:AS & 157. & 255 . & \multicolumn{4}{|c|}{87919.} & & \\
\hline
\end{tabular}

SECOND USER DEFINED TABLE.

$\begin{array}{ccrrrrrrrr}\text { XSID : CODE } & \text { CRWS } & \text { FR\# } & \text { YMIN } & \text { YMAX } & \text { HF } & \text { HO } & \text { VHD } & \text { EGL } & \text { WSEL } \\ \text { EXITX:XS } & 488.47 & 0.49 & 477.99 & 512.25 * * * * * * * * * * & 0.44 & 490.16 & 489.73 \\ \text { FULLV:FV } & * * * * * * * * & 0.63 & 478.78 & 513.04 & 0.36 & 0.09 & 0.63 & 490.61 & 489.98 \\ \text { BRIDG : BR } & 487.21 & 0.64 & 478.78 & 494.54 & 0.65 & 1.82 & 1.95 & 492.63 & 490.68 \\ \text { RDWAY:RG } & * * * * * * * * * * * * * * * & 487.63 & 507.45 & 0.05 * * * * * * & 0.14 & 493.25 & 492.32 \\ \text { APPRO:AS } & 489.02 & 0.20 & 478.53 & 511.66 & 0.52 & 0.16 & 0.14 & 493.32 & 493.18\end{array}$


WSPRO OUTPUT FILE (continued)

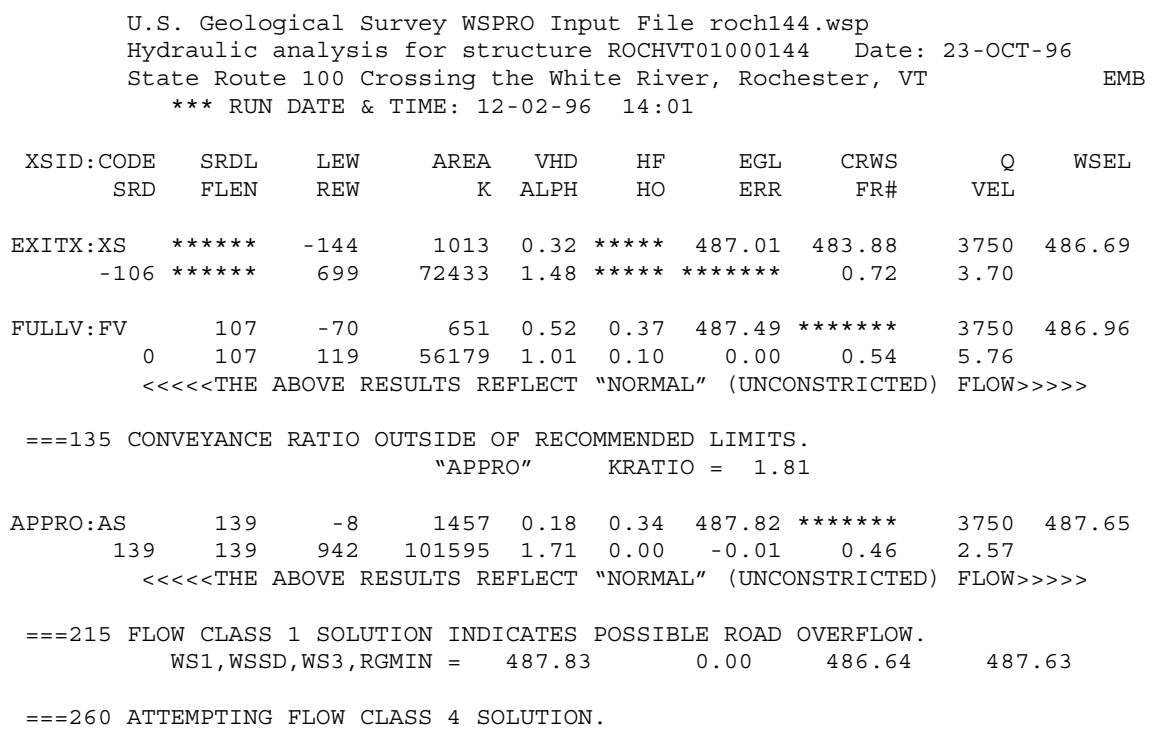

FIRST USER DEFINED TABLE.

\begin{tabular}{|c|c|c|c|c|c|c|c|c|}
\hline XSID : CODE & SRD & LEW & REW & $Q$ & $\mathrm{~K}$ & AREA & VEL & WSEL \\
\hline EXITX:XS & -107 & -145 & 699. & 3750 . & 72433 . & 1013. & 3.70 & 486.69 \\
\hline FULLV : FV & 0 & -71 & 119. & 3750 . & 56179. & 651. & 5.76 & 486.96 \\
\hline BRIDG : BR & 0 & 8. & 96. & 3750 . & 65790. & 539. & 6.95 & 486.64 \\
\hline RDWAY : RG & \multicolumn{3}{|c|}{$20 . * * * * \star * \star * * * * \star * \star * *$} & 0 & 0 & 0 . & \multicolumn{2}{|c|}{ 1. $00 * * * * * * \star *$} \\
\hline APPRO : AS & 139. & -9 & 945. & 3750. & 112597. & 1629. & 2.30 & 487.83 \\
\hline XSID : CODE & XLKQ & XRKQ & & & & & & \\
\hline APPRO : AS & 20 & 108. & 70028 & & & & & \\
\hline
\end{tabular}

SECOND USER DEFINED TABLE.

$\begin{array}{lcrrrrrrrr}\text { XSID:CODE } & \text { CRWS } & \text { FR\# } & \text { YMIN } & \text { YMAX } & \text { HF } & \text { HO } & \text { VHD } & \text { EGL } & \text { WSEL } \\ \text { EXITX:XS } & 483.88 & 0.72 & 477.99 & 512.25 * * * * * * * * * * * & 0.32 & 487.01 & 486.69 \\ \text { FULLV:FV } & * * * * * * * & 0.54 & 478.78 & 513.04 & 0.37 & 0.10 & 0.52 & 487.49 & 486.96 \\ \text { BRIDG:BR } & 484.03 & 0.54 & 478.78 & 494.54 & 0.32 & 0.21 & 0.90 & 487.54 & 486.64 \\ \text { RDWAY:RG } & * * * * * * * * * * * * * * & 487.63 & 507.45 & 0.11 * * * * * & 0.14 & 487.85 * * * * * * \\ \text { APPRO:AS } & 484.30 & 0.41 & 478.53 & 511.66 & 0.26 & 0.17 & 0.14 & 487.97 & 487.83 \\ \text { ER } & & & & & & & & & \end{array}$




\section{APPENDIX C:}

\section{BED-MATERIAL PARTICAL-SIZE DISTRIBUTION}




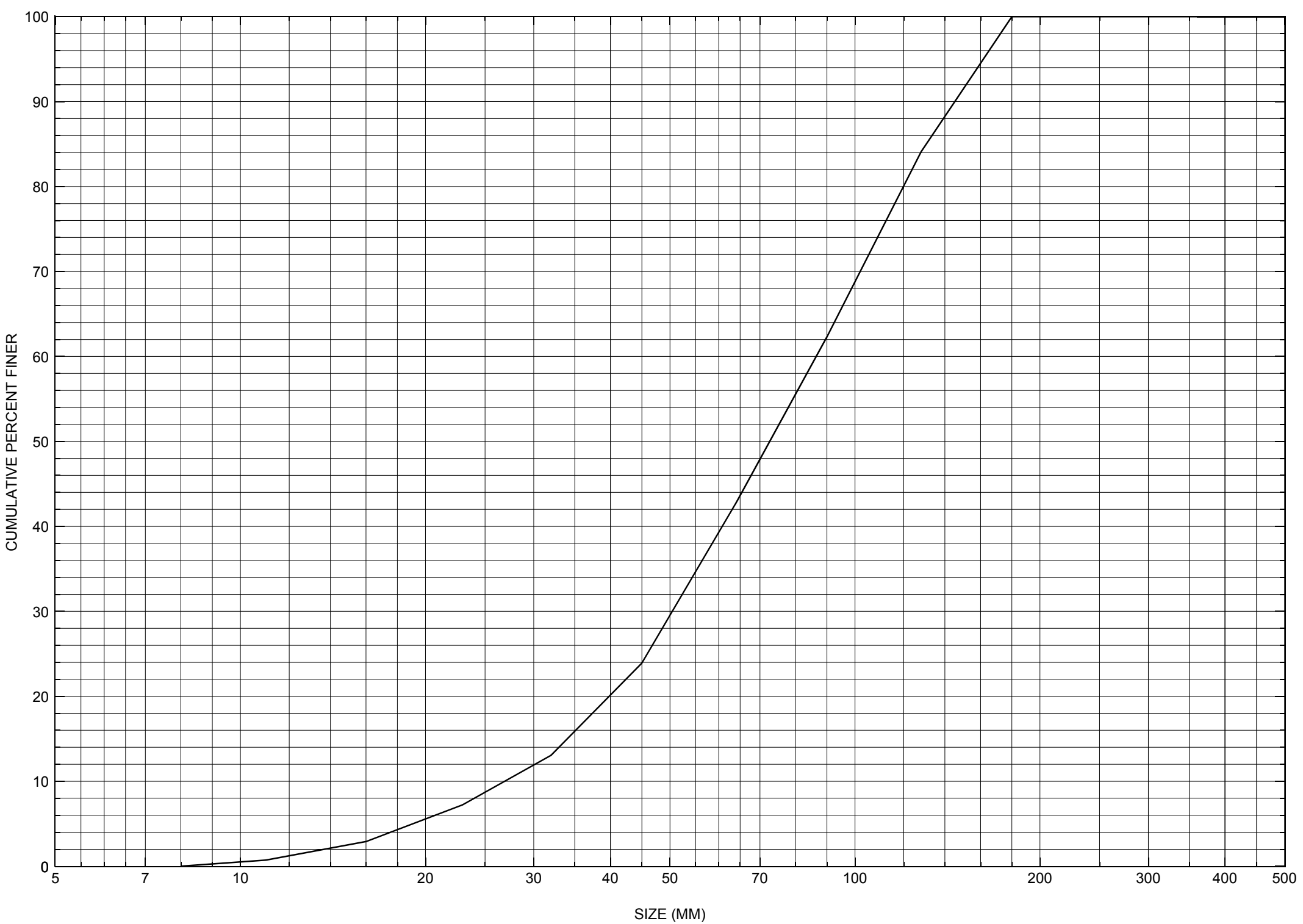

Appendix C. Bed material particle-size distribution for one pebble count transect in the channel approach of structure ROCHVT01000144, in Rochester, Vermont. 


\section{APPENDIX D: \\ HISTORICAL DATA FORM}




\section{Structure Number ROCHVT01000144}

\section{General Location Descriptive}

Data collected by (First Initial, Full last name) $\underline{\text { L }}$. MEDALIE

Date $(M M / D D / Y Y) \_\mathbf{0 3} / \underline{\mathbf{0 8}} / \underline{\mathbf{9 5}}$

Highway District Number (I - 2; nn) $\mathbf{0 4}$

Town (FIPS place code; I - 4; nnnnn) $\mathbf{6 0 1 0 0}$

Waterway (I - 6) White River

Route Number VT100

Topographic Map Hancock

Latitude (I - 16; nnnn.n) 43539
County (FIPS county code; I - 3; nnn)

Mile marker (I - 11; nnn.nnn) $\mathbf{0 0 7 2 3 0}$

Road Name (I - 7): -

Vicinity (I - 9) 2.6 MI N JCT. VT.73

Hydrologic Unit Code:

Longitude (i - 17; nnnnn.n) $\mathbf{7 2 4 9 3}$

\section{Select Federal Inventory Codes}

FHWA Structure Number $(I$ - 8) $\mathbf{2 0 0 0 1 3 0 1 4 4 1 4 1 5}$

Maintenance responsibility $(I-21 ; n n)$

Year built (I - 27; YYYY) 1983

Average daily traffic, ADT (I - 29; nnnnnn) 001990

Year of ADT (I - 30; YY) $\mathbf{9 2}$

Opening skew to Roadway $(I-34 ; n n)$

Operational status $(I-41 ; X)$ A

Structure type (I - 43; nnn) $\mathbf{3 0 2}$

Approach span structure type $(I-44 ; n n n)$ 000

Number of spans (I - 45; nnn) $\mathbf{0 0 1}$

Number of approach spans (I - 46; nnnn) $\mathbf{0 0 0 0}$

Comments:

The structural inspection report of $9 / 30 / 93$ indicates the structure is a single span, steel stringer type bridge. The left abutment wall has some cracking with leakage reported. The wingwalls of the left abutment are in good condition, with the exception of some minor cracking noted. Both abutments are protected with stone fill. The channel takes a moderate turn into the structure, and currently flows along the right abutment side, predominantly. There is a sand and stone point bar deposited on the left abutment side of channel. The footings are not exposed and no apparent settlement has occurred. Minor channel scour along right abutment is reported.
Maximum span length (I - 48; nnnn) $\underline{\mathbf{0 1 0 1}}$

Structure length (I - 49; nnnnnn) $\underline{\mathbf{0 0 0 1 0 3}}$

Deck Width (I - 52; nn.n) $\mathbf{4 1 2}$

Channel \& Protection $(I-61 ; n) \underline{7}$

Waterway adequacy $(I-71 ; n) \underline{8}$

Underwater Inspection Frequency $(I-92 B ; X Y Y) \_$N

Year Reconstructed (I - 106) $\mathbf{0 0 0 0}$

Clear span (nnn.n ft) $\mathbf{9 7 . 5}$

Vertical clearance from streambed (nnn.n ft) $\underline{\mathbf{1 8 . 7}}$

Waterway of full opening $\left(n n n . n \mathrm{ft}^{2}\right) \mathbf{1 8 2 0}$ 


\section{Bridge Hydrologic Data}

Is there hydrologic data available? $\underline{\mathbf{Y}}$ if No, type ctrl- $n$ VTAOT Drainage area $\left(m i^{2}\right): \underline{\mathbf{6 8 . 8 5}}$

Terrain character: Rolling hills to mountainous

Stream character \& type: Tributary of the Connecticut River; type-meandering.

Streambed material: Sand-gravel

Discharge Data (cfs): $\quad \mathrm{Q}_{2.33}$

$Q_{50} \mathbf{1 3 0 0 0}$

\begin{tabular}{lll}
$\mathrm{Q}_{10} \frac{\mathbf{6 5 0 0}}{\mathbf{1 5 5 0 0}}$ & $\mathrm{Q}_{25} \stackrel{\mathbf{1 0 2 0 0}}{\mathrm{Q}_{100}} \mathrm{Q}_{500}-$ \\
\hline
\end{tabular}

Record flood date $(M M / D D / Y Y):-[/ / 27$ Water surface elevation (ff):

Estimated Discharge (cfs): __ Velocity at Q $\underline{\mathbf{5 0}}$ (ft/s): $\underline{\mathbf{5 . 7}}$

Ice conditions (Heavy, Moderate, Light): Moderate Debris (Heavy, Moderate, Light): Moderate

The stage increases to maximum highwater elevation (Rapidly, Not rapidly): Not rapidly

The stream response is (Flashy, Not flashy): Not flashy

Describe any significant site conditions upstream or downstream that may influence the stream's

stage: Stage is not affected by downstream conditions

Watershed storage area (in percent): 1 \%

The watershed storage area is: $\mathbf{2}$ (1-mainly at the headwaters; 2- uniformly distributed; 3-immediatly upstream oi the site)

Water Surface Elevation Estimates for Existing Structure:

\begin{tabular}{|l|l|l|l|l|l|}
\hline Peak discharge frequency & $Q_{2.33}$ & $Q_{10}$ & $Q_{25}$ & $Q_{50}$ & $Q_{100}$ \\
Water surface elevation $(f t))$ & $\mathbf{8 4 8 . 6}$ & $\mathbf{8 5 1 . 9}$ & $\mathbf{8 5 4 . 1}$ & $\mathbf{8 5 5 . 2}$ & $\mathbf{8 5 6 . 3}$ \\
Velocity $(f t / s e c)$ & $\mathbf{5 . 2}$ & $\mathbf{7 . 3}$ & $\mathbf{9 . 2}$ & $\mathbf{1 0 . 4}$ & $\mathbf{1 1 . 8}$ \\
\hline
\end{tabular}

Long term stream bed changes: -

Is the roadway overtopped below the $\mathrm{Q}_{100}$ ? (Yes, No, Unknown): $\underline{\mathbf{Y}} \quad$ Frequency: $\underline{\mathbf{Q 5}}$

Relief Elevation $(f t): \underline{\mathbf{8 5 0 . 0}}$ Discharge over roadway at $\mathrm{Q}_{100}\left(f t^{3} / \mathrm{sec}\right)$ :

Are there other structures nearby? (Yes, No, Unknown): $\mathbf{Y}$ If No or Unknown, type ctrl-n os Upstream distance (miles): 1.7 Town: Hancock $\quad$ Year Built:

Highway No. : TH-1 Structure No. : 10 Structure Type:

Clear span $(f t): \underline{\mathbf{8 6}}$ Clear Height $(f t): \underline{\mathbf{8}}$ Full Waterway $\left(f^{2}\right): \underline{\mathbf{6 8 8}}$ 
Downstream distance (miles): $\underline{\mathbf{1 . 0}}$ Town: Year Built:

Highway No. : $\mathbf{T H - 1 8}$ Structure No. : 29 Structure Type:

Clear span (ft): $\underline{\mathbf{5}}$ Clear Height $(f t): \underline{18}$ Full Waterway $\left(f^{2}\right): 1044$

Comments:

\section{USGS Watershed Data}

Watershed Hydrographic Data

Drainage area $(D A) \quad 68.91 \quad \mathrm{mi}^{2}$

Watershed storage (ST) 0.1

Bridge site elevation 840 Main channel length 12.4 $10 \%$ channel length elevation $\mathbf{8 6 0}$ mi $\%$

Lake and pond area

0.04 $\mathrm{mi}^{2}$ Headwater elevation $\quad \mathbf{3 7 8 0} \mathrm{ft}$ Main channel slope $(S) \quad \mathbf{9 6 . 7 7} \mathrm{ft} / \mathrm{mi}$

Watershed Precipitation Data

Average site precipitation in Average headwater precipitation in

Maximum 2yr-24hr precipitation event $(124,2)$ in

Average seasonal snowfall (Sn) $\mathrm{ft}$ 


\section{Bridge Plan Data}

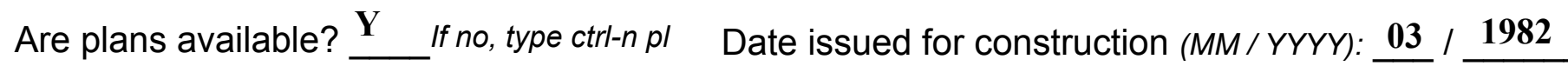
Project Number BRF 013-4(6)S

Minimum channel bed elevation: $\mathbf{8 4 0 . 5}$

Low superstructure elevation: USLAB $\underline{\mathbf{8 5 6 . 8 5}}$ DSLAB $\underline{\mathbf{8 5 6 . 9 4}}$ USRAB $\underline{\mathbf{8 5 3 . 9 5}}$ DSRAB $\mathbf{8 5 4 . 3 4}$

Benchmark location description:

Chiseled square on top of the upstream end of the upstream left wingwall on the old bridge which crossed just upstream, elevation 853.95. This may no longer exist.

Reference Point (MSL, Arbitrary, Other): MSL Datum (NAD27, NAD83, Other): NGVD1929 Foundation Type: 1 (1-Spreadfooting; 2-Pile; 3- Gravity; 4-Unknown)

If 1: Footing Thickness $\mathbf{2 . 0}$ Footing bottom elevation: $\underline{\mathbf{8 4 2 . 0}}$ *

If 2: Pile Type: ___ (1-Wood; 2-Steel or metal; 3-Concrete) Approximate pile driven length: -

If 3: Footing bottom elevation: -

Is boring information available? $\underline{\mathbf{Y}}$ If no, type ctrl-n bi Number of borings taken: $\underline{\mathbf{2}}$

Foundation Material Type: 1 (1-regolith, 2-bedrock, 3-unknown)

Briefly describe material at foundation bottom elevation or around piles:

Sandy gravel

Comments:

*The right abutment has a proposed bottom elevation as shown above. However, the bottom of footing elevation proposed on the left abutment is 4 feet higher at 846.0. This is also shown in the copy of the boring data in the folder. The abutments appear to be the flow through type in the plans. 


\section{Cross-sectional Data}

Is cross-sectional data available? $\mathbf{N}$ If no, type ctrl-n xs

Source (FEMA, VTAOT, Other)? -

Comments: NO CROSS SECTION INFORMATION

\begin{tabular}{|l|l|l|l|l|l|l|l|l|l|l|l|}
\hline Station & - & - & - & - & - & - & - & - & - & - & - \\
\hline Feature & - & - & - & - & - & - & - & - & - & - & - \\
\hline $\begin{array}{l}\text { Low cord } \\
\text { elevation }\end{array}$ & - & - & - & - & - & - & - & - & - & - & - \\
\hline $\begin{array}{l}\text { Bed } \\
\text { elevation }\end{array}$ & - & - & - & - & - & - & - & - & - & - & - \\
\hline $\begin{array}{l}\text { Low cord to } \\
\text { bed length }\end{array}$ & - & - & - & - & - & - & - & - & - & - & - \\
\hline Station & - & - & - & - & - & - & - & - & - & - & - \\
\hline Feature & - & - & - & - & - & - & - & - & - & - & - \\
\hline $\begin{array}{l}\text { Low cord } \\
\text { elevation }\end{array}$ & - & - & - & - & - & - & - & - & - & - & - \\
\hline $\begin{array}{l}\text { Bed } \\
\text { elevation }\end{array}$ & - & - & - & - & - & - & - & - & - & - & - \\
\hline $\begin{array}{l}\text { Low cord to } \\
\text { bed length }\end{array}$ & - & - & - & - & - & - & - & - & - & - & - \\
\hline
\end{tabular}

Source (FEMA, VTAOT, Other)?

Comments: NO CROSS SECTION INFORMATION

\begin{tabular}{|l|l|l|l|l|l|l|l|l|l|l|l|}
\hline Station & - & - & - & - & - & - & - & - & - & - & - \\
\hline Feature & - & - & - & - & - & - & - & - & - & - & - \\
\hline $\begin{array}{l}\text { Low cord } \\
\text { elevation }\end{array}$ & - & - & - & - & - & - & - & - & - & - & - \\
\hline $\begin{array}{l}\text { Bed } \\
\text { elevation }\end{array}$ & - & - & - & - & - & - & - & - & - & - & - \\
\hline $\begin{array}{l}\text { Low cord to } \\
\text { bed length }\end{array}$ & - & - & - & - & - & - & - & - & - & - & - \\
\hline Station & - & - & - & - & - & - & - & - & - & - & - \\
\hline Feature & - & - & - & - & - & - & - & - & - & - & - \\
\hline $\begin{array}{l}\text { Low cord } \\
\text { elevation }\end{array}$ & - & - & - & - & - & - & - & - & - & - & - \\
\hline $\begin{array}{l}\text { Bed } \\
\text { elevation }\end{array}$ & - & - & - & - & - & - & - & - & - & - & - \\
\hline $\begin{array}{l}\text { Low cord to } \\
\text { bed length }\end{array}$ & - & - & - & - & - & - & - & - & - & - & - \\
\hline
\end{tabular}




\section{APPENDIX E: \\ LEVEL I DATA FORM}


U. S. Geological Survey

Bridge Field Data Collection and Processing Form

Qa/Qc Check by: $\mathbf{R B}$

Date: $09 / 27 / 96$

\section{Structure Number}

\section{A. General Location Descriptive}

1. Data collected by (First Initial, Full last name) $\underline{\text { E. WILD }}$

2. Highway District Number 04

Date $(M M / D D / Y Y) \underline{\mathbf{0 7}} / \underline{\mathbf{2 2}} / \underline{1996}$

County Windsor (027)

Mile marker $\mathbf{0 0 7 2 3 0}$

Waterway (I - 6) White River

Route Number VT100

Town Rochester (60100)

Road Name -

Hydrologic Unit Code: 01080105

3. Descriptive comments:

Located 2.6 miles north of junction with VT 73. This is a single span, steel stringer type bridge. Plaque on the bridge stamped with project number '013-4(6)S' and dated 1983.

\section{B. Bridge Deck Observations}
4. Surface cover... LBUS 4
RBUS 4
LBDS 4
RBDS 4
Overall 4

(2b us, ds,lb,rb: 1- Urban; 2- Suburban; 3- Row crops; 4- Pasture; 5- Shrub- and brushland; 6- Forest; 7- Wetland)
5. Ambient water surface... US $\underline{2}$
UB 2
DS 2
(1- pool; 2- riffle)

6. Bridge structure type 1 (1- single span; 2- multiple span; 3- single arch; 4- multiple arch; 5-cylindrical culvert; 6- box culvert; or 7- other)
7. Bridge length 103
(feet)
Span length $\mathbf{1 0 1}$
(feet)
Bridge width 41.2 (feet)

\section{Road approach to bridge:}
8. LB 2 RB 1
( 0 even, 1- lower, 2- higher)
9. LB 1
RB 1
(1- Paved, 2- Not paved)

10. Embankment slope (run / rise in feet / foot):

US left 1.3:1

US right 1.3:1

\begin{tabular}{|c|c|c|c|c|}
\hline & \multicolumn{2}{|c|}{ Protection } & \multirow{2}{*}{ 13.Erosion } & \multirow{2}{*}{ 14.Severity } \\
\hline & 11.Type & 12.Cond. & & \\
\hline LBUS & $\mathbf{0}$ & - & $\mathbf{0}$ & - \\
\hline RBUS & $\mathbf{0}$ & - & $\mathbf{0}$ & - \\
\hline RBDS & $\mathbf{0}$ & - & $\mathbf{0}$ & - \\
\hline LBDS & $\mathbf{0}$ & - & $\mathbf{0}$ & - \\
\hline
\end{tabular}

Bank protection types: 0- none; 1- < 12 inches;

2- < 36 inches; 3- < 48 inches;

4- < 60 inches; 5- wall / artificial levee

Bank protection conditions: 1- good; 2- slumped;

3- eroded; 4- failed

Erosion: 0 - none; 1- channel erosion; 2-

road wash; 3- both; 4- other

Erosion Severity: 0 - none; 1- slight; 2- moderate; 3- severe

\section{Channel approach to bridge (BF):}

15. Angle of approach: $\mathbf{5}$

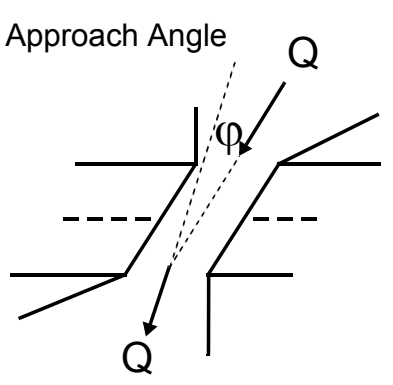

17. Channel impact zone 1:

Where? LB $(L B, R B)$

Range? 250 feet US

Channel impact zone 2:

Where? - $\quad(L B, R B)$

Range? - $\quad$ feet (US, UB, DS) to feet -

Impact Severity: 0- none to very slight; 1- Slight; 2- Moderate; 3- Severe
16. Bridge skew: $\mathbf{1 0}$

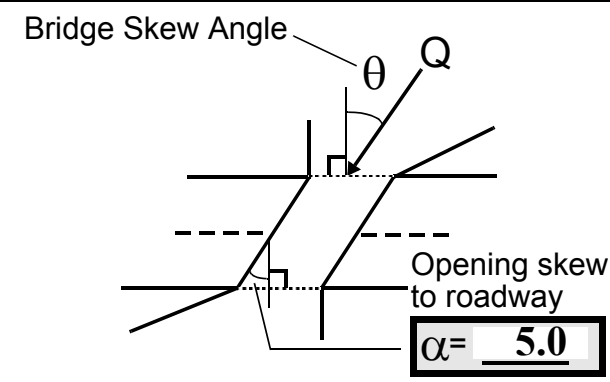

\section{Exist? $\mathbf{Y}(Y$ or $N)$}

Severity 2

(US, UB, DS) to $\underline{47 \quad \text { feet } \underline{\mathbf{U S}}}$

Exist? $\mathbf{N}(Y$ or $N)$

Severity -

o roadway 
18. Bridge Type: $\mathbf{3}$

1a- Vertical abutments with wingwalls

1 b- Vertical abutments without wingwalls

2- Vertical abutments and wingwalls, sloping embankment

Wingwalls perpendicular to abut. face

3- Spill through abutments

4- Sloping embankment, vertical wingwalls and abutments

Wingwall angle less than $90^{\circ}$.
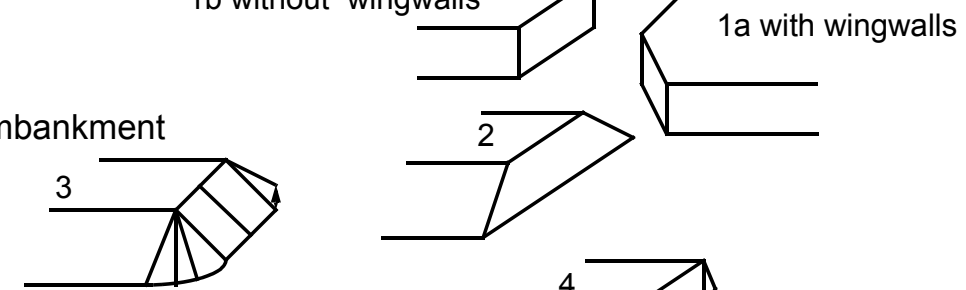

19. Bridge Deck Comments (surface cover variations, measured bridge and span lengths, bridge type variations, approach overflow width, etc.)

7. Values are from the VT AOT files. Measured bridge dimensions are the same.

10. Embankment slopes were not surveyed and could not be computed. However, both were estimated for hydraulic analysis based on discussion with the personnel in the field at this site. The slope on each side was estimated at 1.3:1.

\section{Upstream Channel Assessment}

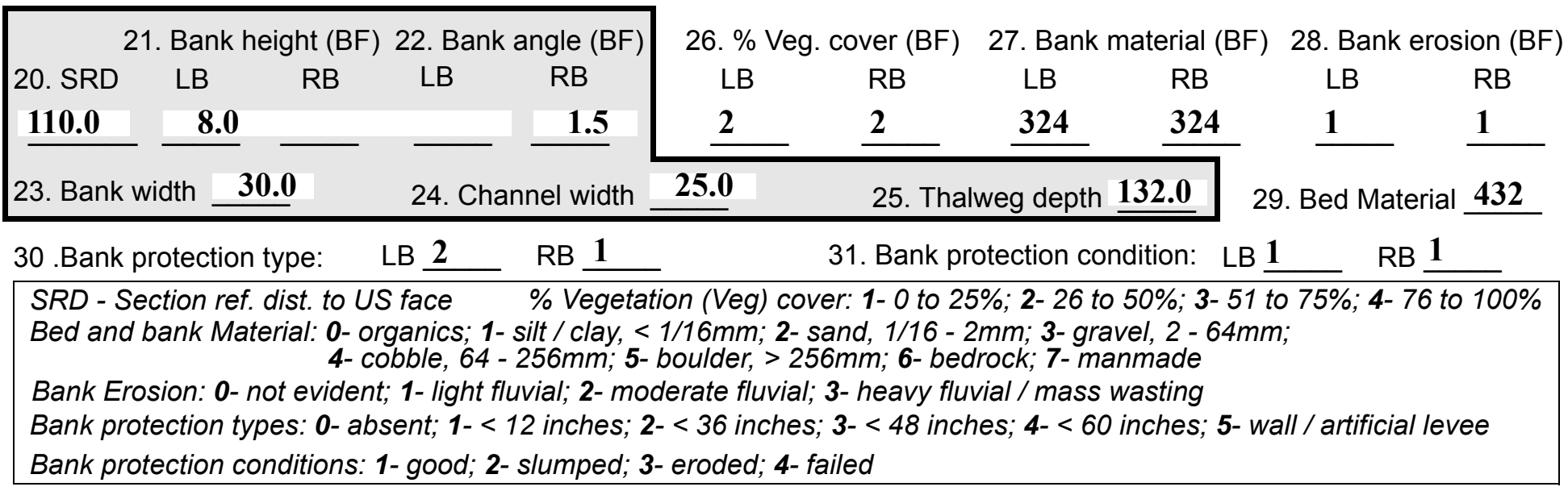

32. Comments (bank material variation, minor inflows, protection extent, etc.):

30. The right bank protection extends from $0 \mathrm{ft}$. US to $24 \mathrm{ft}$. US. The left bank protection is from $87 \mathrm{ft}$. US to 0 ft. US and extends an additional $20 \mathrm{ft}$. along the left bank of the confluence from where it enters the White River.

The river is locally anabranched. From $335 \mathrm{ft}$. US to $124 \mathrm{ft}$. US there is a channel bar positioned from $30 \% \mathrm{LB}$ to $50 \% \mathrm{RB}$. It is comprised of gravel and cobbles and is vegetated with grass and small bushes. 
38. Point or side bar comments (Circle Point or Side; Note additional bars, material variation, status, etc.):

On the left side of this point bar at mid-bar distance is where the confluence enters into the White River. The point bar is more vegetated on the US end and grades from fine to coarse moving from right to left. An additional bar is from $90 \mathrm{ft}$. US to $65 \mathrm{ft}$. US. It is comprised of cobble and is vegetated with grass. It is positioned from $25 \% \mathrm{LB}$ to $40 \% \mathrm{RB}$ and the mid-bar distance is at $87 \mathrm{ft}$. US.

\section{Is a cut-bank present? $\mathbf{Y}$ (Y or if $N$ type ctrl-n $c b) \quad$ 40. Where? LB (LB or RB)}

41. Mid-bank distance: $\underline{\mathbf{1 0 8}}$ 42. Cut bank extent: 161 feet $\underline{\mathrm{US}}$ (US, UB) to $\underline{\mathbf{9 5}}$ feet $\underline{\mathrm{US}}$ (US, UB, DS)

43. Bank damage: 1 (1- eroded and/or creep; 2- slip failure; 3- block failure)

44. Cut bank comments (eg. additional cut banks, protection condition, etc.):

45. Is channel scour present? $\mathbf{Y}$ (Y or if $N$ type ctrl-n cs) $\quad$ 46. Mid-scour distance: $\underline{\mathbf{6 0}}$

47. Scour dimensions: Length $\underline{33}$ Width $\underline{14}$ Depth : $\underline{\mathbf{0 . 5}}$ Position $\underline{45} \%$ LB to $\underline{\mathbf{5 5}} \%$ RB

48. Scour comments (eg. additional scour areas, local scouring process, etc.):

Scour depth assumes a thalweg depth of $3 \mathbf{f t}$.

49. Are there major confluences? $\mathbf{Y}$ ( $Y$ or if $N$ type ctrl- $n \mathrm{mc}$ )

51. Confluence 1: Distance $\underline{87}$

Confluence 2: Distance -
50. How many? 1

53. Type 1 (1- perennial; 2- ephemeral)

Type (1- perennial; 2- ephemeral)

54. Confluence comments (eg. confluence name):

The tributary is Marshs brook.

\section{Under Bridge Channel Assessment}

55. Channel restraint (BF)? LB 2

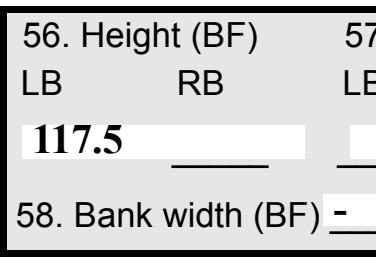
(1- natural bank; 2- abutment; 3- artificial levee)

Bed and bank Material: 0- organics; 1- silt / clay, < 1/16mm; 2- sand, 1/16 - 2mm; 3- gravel, 2 - 64mm; 4- cobble, 64 - 256mm; 5- boulder, > 256mm; 6- bedrock; 7- manmade

Bank Erosion: 0- not evident; 1- light fluvial; 2- moderate fluvial; 3- heavy fluvial / mass wasting

64. Comments (bank material variation, minor inflows, protection extent, etc.):

324

Bank material in front of the even abutments is dumped type 2 stone. 
65. Debris and Ice Is there debris accumulation?

$(Y$ or $N)$ 66. Where? $\underline{Y}$

(1- Upstream; 2- At bridge; 3- Both)

67. Debris Potential 1 (1-Low; 2-Moderate; 3- High)

68. Capture Efficiency 2

(1-Low; 2- Moderate; 3- High)

69. Is there evidence of ice build-up? 1 ( $Y$ or $N)$

Ice Blockage Potential $\mathbf{N}$

(1- Low; 2- Moderate; 3- High)

70. Debris and Ice Comments:

1

66. There is also debris accumulated DS and in the US confluence.

\begin{tabular}{|l|c|c|c|c|c|c|c|c|}
\hline Abutments & $\begin{array}{c}\text { 71. Attack } \\
\angle \text { (BF) }\end{array}$ & $\begin{array}{c}72 \text {. Slope } \angle \\
\text { (Qmax) }\end{array}$ & $\begin{array}{c}\text { 73. Toe } \\
\text { loc. (BF) }\end{array}$ & $\begin{array}{c}\text { 74. Scour } \\
\text { Condition }\end{array}$ & $\begin{array}{c}75 . \text { Scour } \\
\text { depth }\end{array}$ & $\begin{array}{c}\text { 76. Exposure } \\
\text { depth }\end{array}$ & 77. Material & 78. Length \\
\hline LABUT & & $\mathbf{0}$ & $\mathbf{2 7}$ & $\mathbf{0}$ & $\mathbf{0}$ & - & - & $\mathbf{9 0 . 0}$ \\
\hline RABUT & $\mathbf{1}$ & $\mathbf{0}$ & $\mathbf{2 8}$ & & & $\mathbf{0}$ & $\mathbf{0}$ & $\mathbf{9 8 . 5}$ \\
\hline
\end{tabular}

Pushed: $L B$ or RB

Toe Location (Loc.): 0- even, 1- set back, 2- protrudes

Scour cond.: 0- not evident; 1- evident (comment); 2- footing exposed; 3-undermined footing; 4- piling exposed; 5- settled; 6- failed

Materials: 1- Concrete; 2- Stone masonry or drywall; 3- steel or metal; 4- wood

79. Abutment comments (eg. undermined penetration, unusual scour processes, debris, etc.):

1

80. Wingwalls:

Exist? Material? Scour Scour Exposure Angle? Length? Condition? depth? depth?

USLWW:

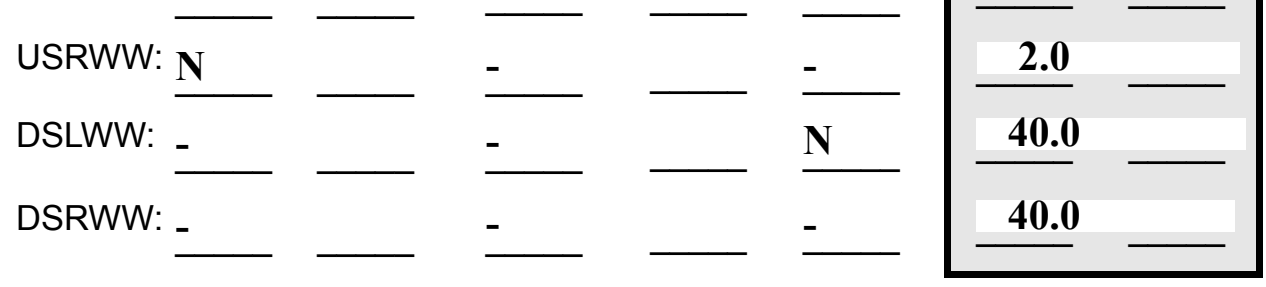

Wingwall materials: 1- Concrete; 2- Stone masonry or drywall; 3- steel or metal; 4- wood

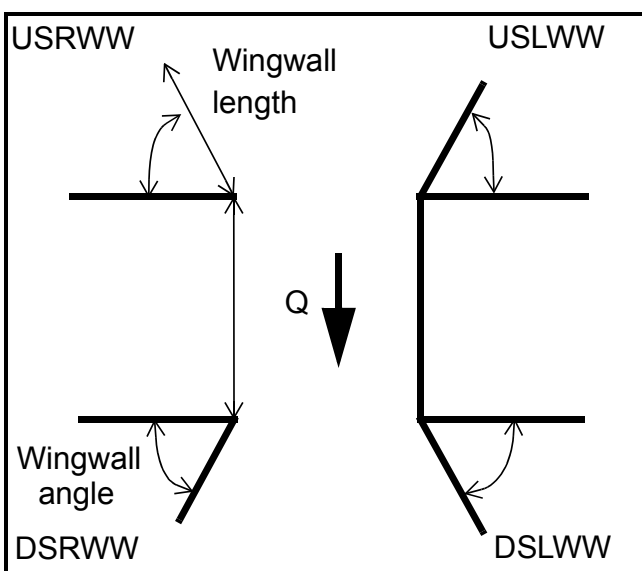

82. Bank / Bridge Protection:

\begin{tabular}{|l|l|l|l|l|l|l|l|c|}
\hline Location & USLWW & USRWW & LABUT & RABUT & LB & RB & DSLWW & DSRWW \\
\hline Type & - & - & N & - & - & - & $\mathbf{1}$ & $\mathbf{1}$ \\
\hline Condition & $\mathbf{N}$ & - & - & - & - & - & $\mathbf{1}$ & $\mathbf{1}$ \\
\hline Extent & - & - & - & - & - & $\mathbf{2}$ & $\mathbf{2}$ & - \\
\hline
\end{tabular}

Bank / Bridge protection types: 0- absent; 1- < 12 inches; 2- < 36 inches; 3- < 48 inches; 4- < 60 inches; 
83. Wingwall and protection comments (eg. undermined penetration, unusual scour processes, etc.):

-
-
-
-
-
-
-
-

\section{Piers:}

84. Are there piers? _ _ (Y or if $N$ type ctrl-n pr)

\begin{tabular}{|l|l|l|l|l|l|l|l|}
\hline \multirow{2}{*}{$\begin{array}{l}85 . \\
\text { Pier no. }\end{array}$} & \multicolumn{3}{|c|}{ width (w) feet } & \multicolumn{3}{c|}{ elevation (e) feet } \\
\cline { 2 - 9 } & w1 & w2 & w3 & e@w1 & e@w2 & e@w3 \\
\hline Pier 1 & - & - & - & - & - & - \\
\hline Pier 2 & - & - & - & - & - & - \\
\hline Pier 3 & - & - & - & - & - & - & - \\
\hline Pier 4 & - & - & - & - & - & w1 \\
\hline
\end{tabular}

\begin{tabular}{|l|l|l|l|l|}
\hline Level 1 Pier Descr. & 1 & \multicolumn{1}{|c|}{2} & 3 & \multicolumn{1}{|c|}{} \\
\hline 86. Location (BF) & & - & - & - \\
\hline 87. Type & & - & - & - \\
\hline 88. Material & & - & - & - \\
\hline 89. Shape & & - & - & - \\
\hline 90. Inclined? & & - & - & - \\
\hline 91. Attack $\angle$ (BF) & & - & - & - \\
\hline 92. Pushed & & - & - & - \\
\hline 93. Length (feet) & - & - & - & - \\
\hline 94. \# of piles & & - & - & - \\
\hline 95. Cross-members & & - & - & - \\
\hline 96. Scour Condition & & - & - & - \\
\hline 97. Scour depth & $\mathbf{N}$ & - & - & - \\
\hline 98. Exposure depth & - & - & - & - \\
\hline
\end{tabular}

LFP, LTB, LB, MCL, MCM, MCR, RB, RTB, RFP

1- Solid pier, 2- column, 3- bent

1-Wood; 2- concrete; 3- metal; 4- stone

1- Round; 2- Square; 3- Pointed

Y-yes; $N$ - no

$L B$ or $R B$

0- none; 1- laterals; 2- diagonals; 3- both

0- not evident; 1- evident (comment);

2- footing exposed; 3- piling exposed;

4- undermined footing; 5- settled; 6- failed 
99. Pier comments (eg. undermined penetration, protection and protection extent, unusual scour processes, etc.):

-

100.

\section{E. Downstream Channel Assessment}

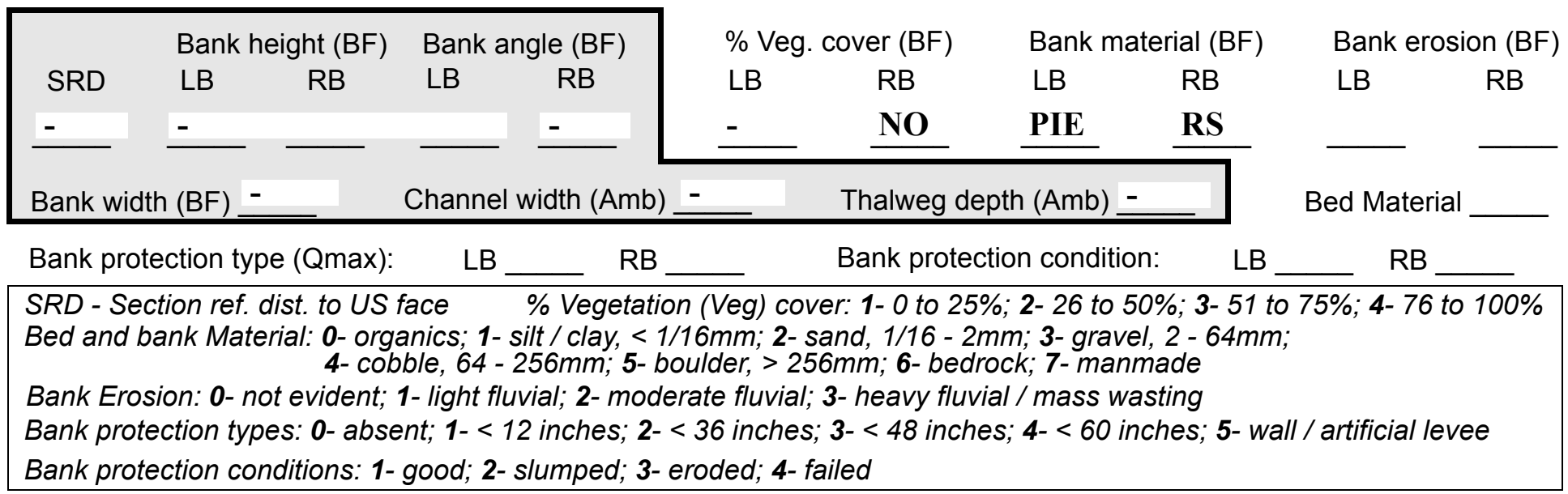

Comments (eg. bank material variation, minor inflows, protection extent, etc.):

1
1
324
234
1
1
4352
2
2
1
1

The left and the right bank protection is an extension of the abutment protection. On the left bank it extends from $0 \mathrm{ft}$. DS to $30 \mathrm{ft}$. DS and on the right bank it is from $0 \mathrm{ft}$. DS to $22 \mathrm{ft}$. DS.

101. Is a drop structure present? _ _ ( or $N$, if $N$ type ctrl-n ds) 102. Distance: ___ feet
103. Drop: - feet
104. Structure material:
(1- steel sheet pile; 2- wood pile; 3- concrete; 4- other)

105. Drop structure comments (eg. downstream scour depth): 
Point bar extent: feet

(US, UB, DS) to $\underline{\mathbf{N}}$ feet (US, UB, DS)

DS) positioned \%LB to DR \%RB

Material: $\mathbf{\text { OP }}$

Point or side bar comments (Circle Point or Side; note additional bars, material variation, status, etc.):

\section{STRUCTURE}

Is a cut-bank present? (Y or if $N$ type ctrl- $n$ cb) Where? (LB or $R B)$

Mid-bank distance: $\underline{\mathbf{Y}}$ Cut bank extent: $\underline{34}$ feet $\underline{\mathbf{1 6 3}}$ (US, UB, DS) to $\underline{\mathbf{2 2 0}}$ feet $\underline{\mathrm{DS}}$ (US, UB, DS)

Bank damage: 435 (1- eroded and/or creep; 2- slip failure; 3- block failure)

Cut bank comments (eg. additional cut banks, protection condition, etc.):

DS

15

85

43

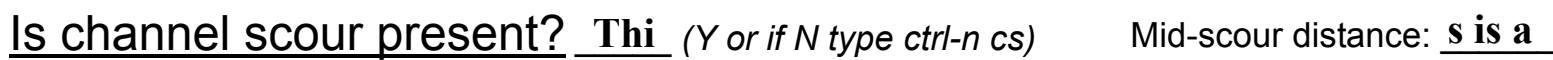
Scour dimensions: Length chan Width nel Depth: $\underline{\text { bar }} \quad$ Positioned wh \%LB to ere $\%$ RB

Scour comments (eg. additional scour areas, local scouring process, etc.):

the stream is anabranched. On either side of the bar it is vegetated with small clumps of brush and grass.

$\mathbf{N}$

Are there major confluences? - $(Y$ or if $N$ type ctrl- $n$ mc)

Confluence 1: Distance -

Enters on (LB or $R B)$

How many? -

Confluence 2: Distance -

Enters on (LB or $R B)$

Type ( 1- perennial; 2- ephemeral)

Confluence comments (eg. confluence name):

Type NO (1-perennial; 2- ephemeral)

\section{CUT BANKS}

\section{F. Geomorphic Channel Assessment}

107. Stage of reach evolution

1- Constructed

2- Stable

3- Aggraded

4- Degraded

5- Laterally unstable

6- Vertically and laterally unstable 
108. Evolution comments (Channel evolution not considering bridge effects; See HEC-20, Figure 1 for geomorphic descriptors):

$\mathbf{N}$

$-$

$-$

$-$

$-$

$-$

NO CHANNEL SCOUR

$\mathbf{N}$ 


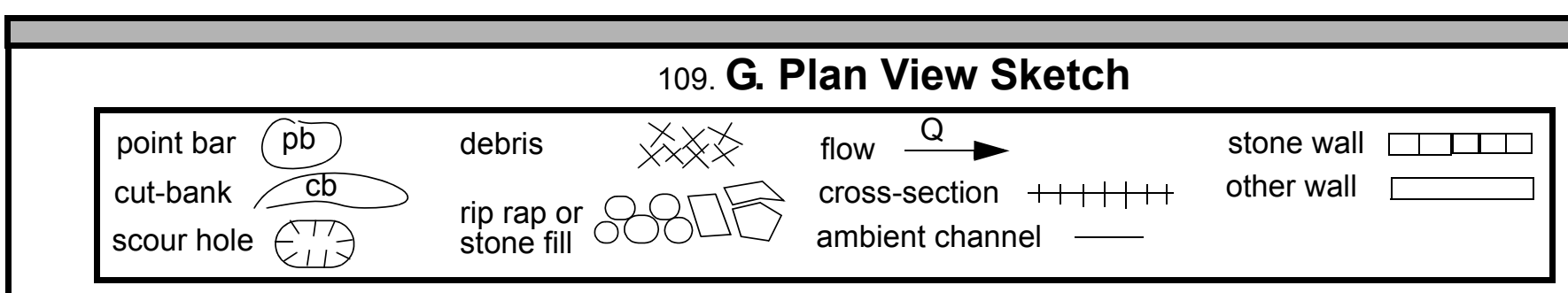


APPENDIX F:

SCOUR COMPUTATIONS 
SCOUR COMPUTATIONS

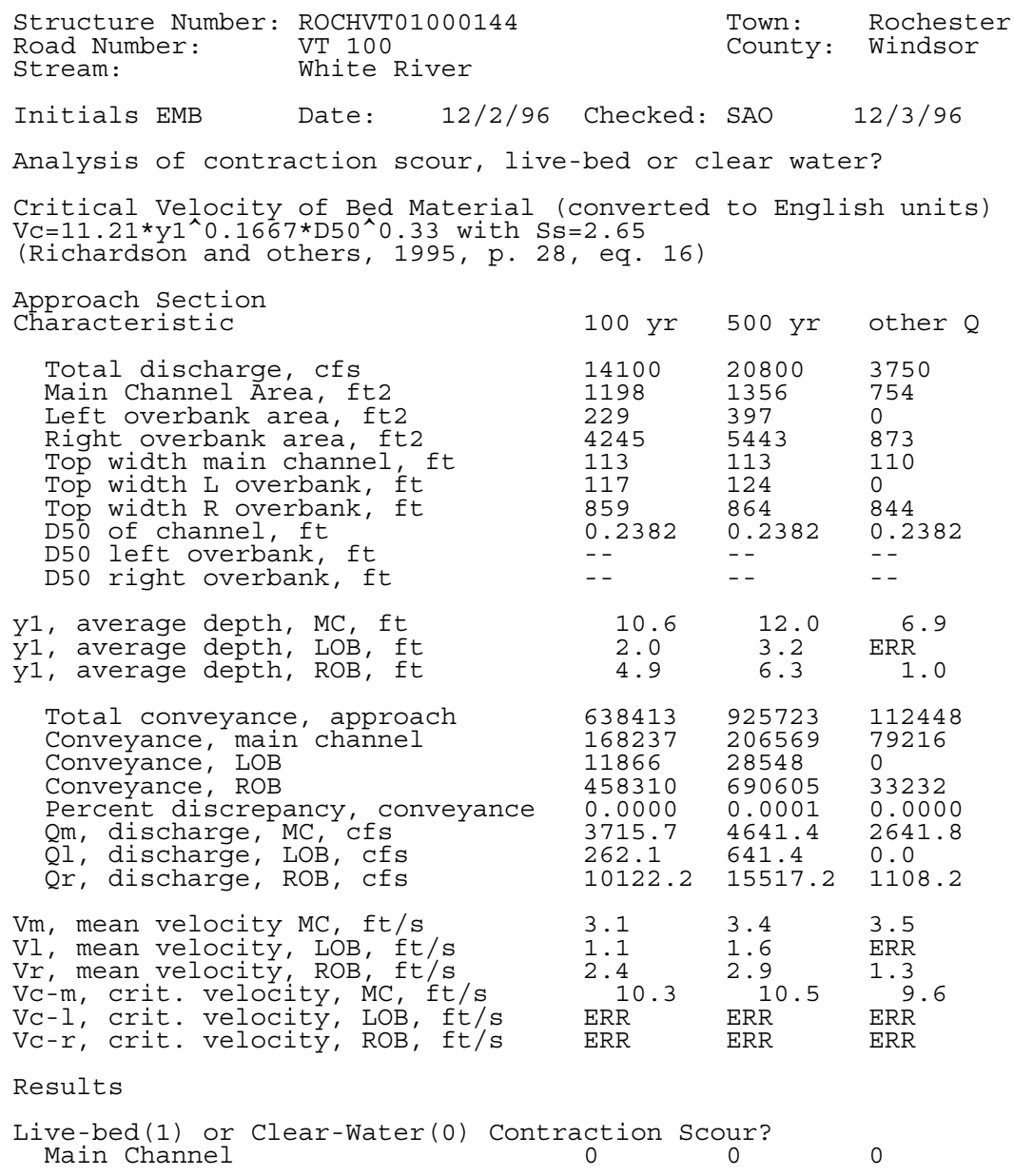


Clear water Contraction Scour in MAIN CHANNEL

\begin{tabular}{|c|c|c|c|}
\hline $\begin{array}{l}\mathrm{y}^{2}=\left(\mathrm{Q} 2^{\wedge} 2 /\left(131 * \mathrm{Dm}^{\wedge}(2 / 3) * \mathrm{~W} 2^{\wedge} 2\right)\right)^{\wedge}( \\
\mathrm{ys}=\mathrm{y} 2-\mathrm{y} \text { bridge } \\
(\mathrm{Richardson} \text { and others, } 1995, \mathrm{p} .\end{array}$ & 7) $\begin{array}{r}\text { Co } \\
\text { eq. } 20\end{array}$ & verted tc & English \\
\hline Approach Section & Q100 & Q500 & Qother \\
\hline $\begin{array}{l}\text { Main channel Area, ft2 } \\
\text { Main channel width, ft } \\
\text { y1, main channel depth, ft }\end{array}$ & $\begin{array}{l}1198 \\
113 \\
10.60\end{array}$ & $\begin{array}{l}1356 \\
113 \\
12.00\end{array}$ & $\begin{array}{r}754 \\
110 \\
6.85\end{array}$ \\
\hline 3ridge section & & & \\
\hline $\begin{array}{l}\text { (Q) total discharge, cfs } \\
\text { (Q) discharge thru bridge, cfs }\end{array}$ & $\begin{array}{l}14100 \\
7214\end{array}$ & $\begin{array}{l}20800 \\
8570\end{array}$ & $\begin{array}{l}3750 \\
3750\end{array}$ \\
\hline $\begin{array}{l}\text { Main channel conveyance } \\
\text { Total conveyance } \\
\text { Q2, bridge MC discharge, cfs } \\
\text { Main channel area, ft2 } \\
\text { Main channel width (skewed), ft } \\
\text { Cum. width of piers in MC, ft } \\
\text { W, adjusted width, ft } \\
\text { y,bridge (avg. depth at br.), ft } \\
\text { Dm, median (1.25*D50), ft } \\
\text { y2, depth in contraction, ft }\end{array}$ & $\begin{array}{l}121169 \\
121169 \\
7214 \\
813 \\
75.3 \\
0.0 \\
75.3 \\
10.80 \\
0.29775 \\
\quad 8.73\end{array}$ & $\begin{array}{l}144690 \\
144690 \\
8570 \\
916 \\
82.3 \\
0.0 \\
82.3 \\
11.13 \\
0.29775 \\
\quad 9.38\end{array}$ & $\begin{array}{l}65839 \\
65839 \\
3750 \\
540 \\
74.6 \\
0.0 \\
74.6 \\
7.23 \\
0.29775 \\
5.03\end{array}$ \\
\hline ys, scour depth (y2-ybridge), ft & -2.06 & -1.75 & -2.21 \\
\hline $\begin{array}{l}\text { ARMORING } \\
\text { D90 } \\
\text { D95 } \\
\text { Critical grain size, Dc, ft } \\
\text { Decimal-percent coarser than DC } \\
\text { Depth to armoring, ft }\end{array}$ & $\begin{array}{l}0.4768 \\
0.5307 \\
0.2513 \\
0.42 \\
1.04\end{array}$ & $\begin{array}{l}0.4768 \\
0.5307 \\
0.2764 \\
0.38 \\
1.35\end{array}$ & $\begin{array}{l}0.4768 \\
0.5307 \\
0.1788 \\
0.625 \\
0.32\end{array}$ \\
\hline
\end{tabular}




\section{Abutment Scour}

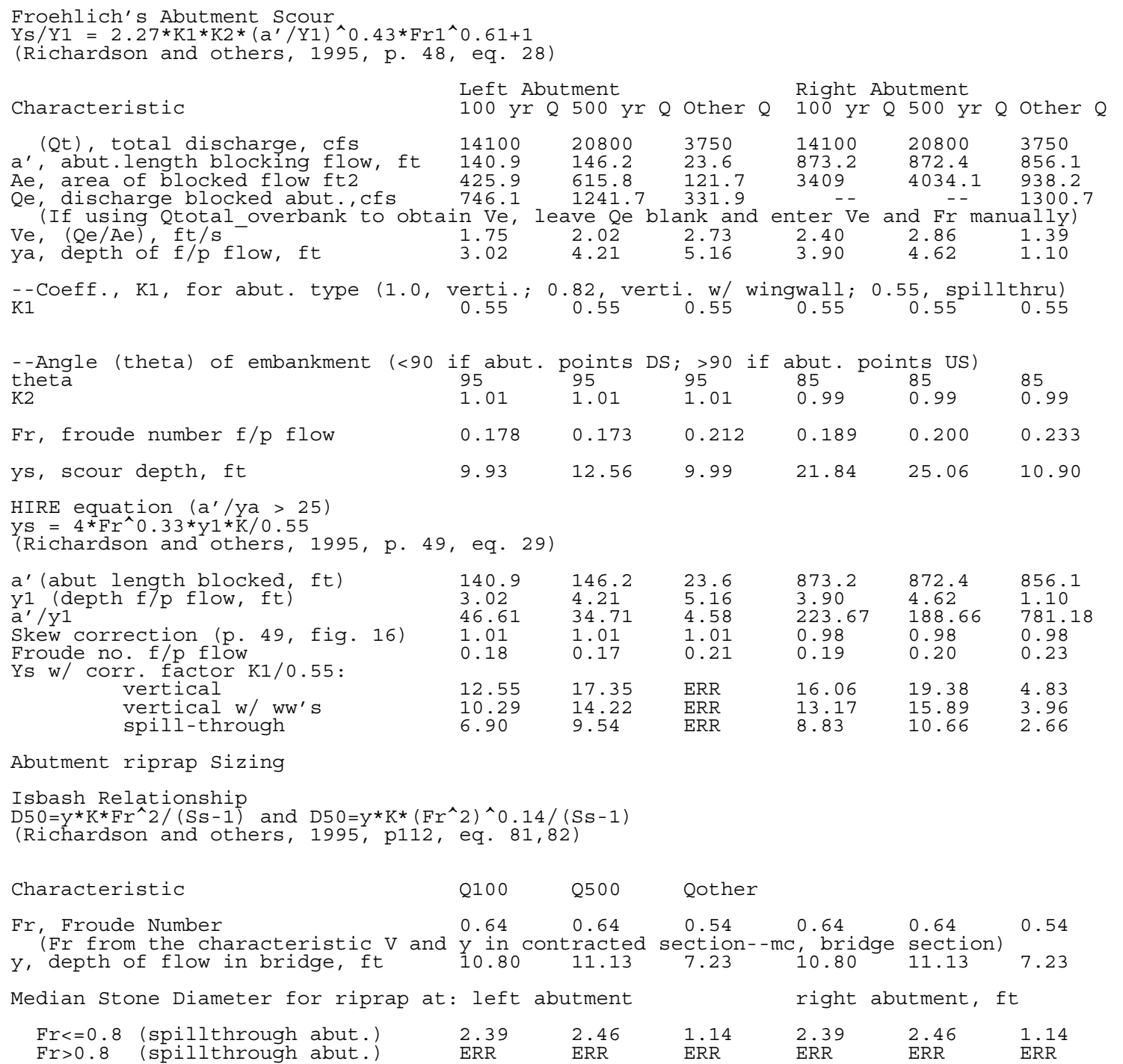

